\title{
Prohibición al asegurado de reconocer su responsabilidad y realizar acuerdos con terceros en el seguro de responsabilidad civil*
}

\author{
Gustavo Andrés Correa Valenzuela*
}

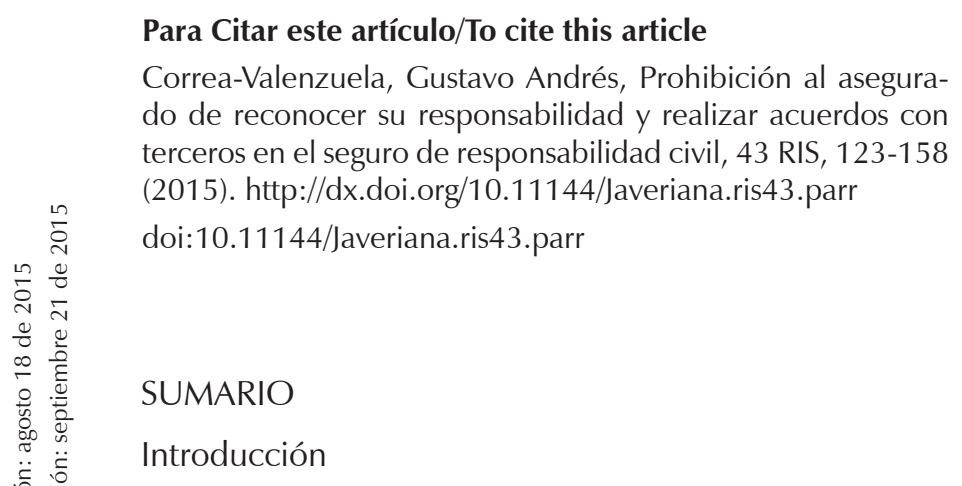

1.1. Prohibición al asegurado de reconocer su responsabilidad y realizar acuerdos con el tercero en el seguro de responsabilidad civil en algunas legislaciones latinoamericanas.

El presente artículo realiza una reflexión respecto de la naturaleza jurídica de la prohibición al asegurado, principalmente en el contexto del régimen jurídico de los deberes del asegurado en el contrato de seguro, pero también analizando los efectos prácticos y jurídicos del incumplimiento de la prohibición objeto de estudio. Así, el artículo inicia con apreciaciones del régimen jurídico que se ha dado a nivel nacional e internacional a la prohibición estudiada, para concluir el estudio proponiendo la consecuencia jurídica que el autor considera adecuada al incumplimiento de dicha prohibición en el ordenamiento jurídico colombiano.

** Egresado de la Universidad del Rosario con mención meritoria y profundización en derecho comercial, abogado con experiencia en litigios civiles y comerciales. Especializado en Derecho de Seguros en la Universidad Javeriana y profesor designado de la Universidad del Rosario en la asignatura de Contratos Civiles y Mercantiles. Contacto: guancova@ gmail.com 
1.2. Contexto jurídico de la prohibición al asegurado de reconocer su responsabilidad y realizar acuerdos con el tercero en el seguro de responsabilidad civil.

Naturaleza de los deberes del asegurado en razón de su relación con el riesgo asegurable.

2.1. Deberes del asegurado al momento de transferir el riesgo al asegurador.

2.2. Deberes del asegurado durante la asunción del riesgo por parte del asegurador.

2.3. Deberes del asegurado al realizarse el riesgo.

Obligación de evitar que el Siniestro se extienda y propague.

Obligación de dar aviso al asegurador de la ocurrencia de Siniestro.

Obligación de proveer al salvamento de las cosas aseguradas.

Obligación de procurar la subrogación del asegurador, incluyendo no renunciar a sus derechos frente a terceros

Obligación de declarar seguros coexistentes

Naturaleza y consecuencia jurídica de la cláusula que prohíbe al asegurado reconocer su responsabilidad y efectuar acuerdos con el tercero.

3.1. Efectos del reconocimiento de responsabilidad del asegurado y del acuerdo con el tercero.

3.2. Improcedencia de liberación del asegurador de efectuar el pago de indemnización como consecuencia jurídica del incumplimiento de la cláusula prohibitoria.

3.3. Aplicación del artículo 1078 del Código de Comercio a la cláusula que prohíbe al asegurado reconocer su responsabilidad y realizar acuerdos con el tercero.

Conclusiones.

Bibliografía.

\section{RESUMEN}

El estudio abarca genéricamente los deberes del asegurado como contexto del análisis de la prohibición al asegurado en el seguro de responsabilidad civil de no reconocer su responsabilidad ni efectuar acuerdos con terceros. Se estudia el régimen general de los distintos deberes del asegurado en la celebración y la ejecución del contrato de seguro, con mención especial al contrato de seguro de responsabilidad civil por ser en este en el que se contempla la prohibición.

Se analiza la forma en que los deberes del asegurado desarrollan principios rectores del contrato de seguro como la buena fe y el principio indemnizatorio, identificando así su naturaleza y su consecuencia jurídica. Se identifican tres distintas especies de deberes a cargo del asegurado en el contrato de seguro que se distinguen a partir del estado 
temporal del riesgo en el contrato de seguro, bien sea: i) al momento de transferirse al asegurador, ii) siendo asumido por parte del asegurador, y iii) habiéndose realizado estando a cargo del asegurador.

El riesgo es el elemento aleatorio del contrato de seguro que le da el carácter de ser de tracto sucesivo, de manera que el estado temporal del riesgo determina la conducta que deben asumir los intervinientes en el contrato de seguro durante su celebración y ejecución, analizándose puntualmente la conducta que debe asumir el asegurado por ser quien él para quien se establece la prohibición objeto de estudio.

En algunas legislaciones latinoamericanas se observan distintas consecuencias al incumplimiento de esta prohibición. A nivel nacional, es común la asignación de la consecuencia jurídica de pérdida del derecho a la indemnización como también se observa que se establece la prohibición sin contemplar consecuencia jurídica a su incumplimiento. Este estudio plantea que en nuestro ordenamiento esta consecuencia se da como sanción a la mala fe en la reclamación y no es adecuada para el incumplimiento de la prohibición objeto de estudio.

Se analizan los efectos del incumplimiento del reconocimiento de responsabilidad por parte del asegurado y del acuerdo entre este y terceros, proponiendo la consecuencia que se considera jurídicamente adecuada en razón de la naturaleza de la prohibición al asegurado.

Palabras Clave: Seguro de responsabilidad civil, deberes del asegurado, consecuencia jurídica de incumplimiento de deberes del asegurado, obligaciones del asegurado ocurrido el siniestro.

\section{ABSTRACT}

This study considers the insured party's duties in a generic manner, as context for analyzing the prohibition in liability insurance of the insured to recognize his civil liability or arrive at agreements with third-parties. The general framework of law for the different duties of the insured during the execution performance of the insurance contract is studied, with special emphasis on the liability insurance contract, as this is the type of insurance that carries the prohibition.

The way in which the insured party's duties develop primary principles of the insurance contract, such as good faith and the indemnity principle, are analysed, thus identifying their nature and juridical consequences. Three different types of insured's duties in the insurance contract are identified, distinguished by the temporary state of the risk in the aforementioned contract, be they: i) at the moment of transmitting the risk to the insurer, ii) the risk being assumed by the insurer, and iii) the risk having occurred while assumed by the insurer.

Risk is the random element in the insurance contract which gives it the unbroken chain character, so that the temporary state of the risk determines the behavior the parties involved must maintain during the execution and performance of the insuran- 
ce contract, analyzing specifically the insured's behavior as he is the recipient of the prohibition at issue.

In some Latin American legislations different consequences have been contemplated for the breach of this prohibition. , In Colombia, loss of the indemnity right is commonly assigned as a consequence; yet the prohibition without establishing a juridical consequence to its breach is also seen. This study proposes that in the Colombian legal system this consequence implies a penalty to bad faith in the insurance claim, therefore inadequate for the breach of the prohibition under discussion.

This study analyzes the effects of the insured's breach of the prohibition of civil liability recognition and agreements with third-parties, proposing a consequence considered legally adequate attending to the nature of the insured's prohibition.

Key words: Liability insurance, insured's duties, legal consequence of the breach of insured's duties, insured's obligations after the loss event. 


\section{INTRODUCCIÓN}

En virtud del contrato de seguro, surgen distintos tipos de deberes -en sentido amplio- para el asegurado, bien sean establecidos por la Ley o por la voluntad de las partes. Dentro de estos deberes, encontramos que en los distintos clausulados del seguro de responsabilidad civil en el mercado colombiano se establece una prohibición para el asegurado cuyo contenido se contempla, por ejemplo, de la siguiente forma:

"Sin autorización escrita de -Asegurador-, el ASEGURADO no podrá incurrir en gasto alguno, ni hacer pagos, ni celebrar arreglos o transacciones con la víctima del daño o sus causahabientes, ni reconocer ante ellos su propia responsabilidad"1

De la lectura de esta cláusula resulta claro que conlleva para el asegurado el deber de abstenerse de realizar determinadas conductas, obligaciones de no hacer. No obstante, en esta cláusula y otras en el mercado colombiano encontramos que no se contempla cuál es la consecuencia de su incumplimiento.

En seguros de responsabilidad civil de otros aseguradores nacionales hemos encontrado que comúnmente se prevé una consecuencia jurídica para el incumplimiento de esta prohibición, contemplando, por ejemplo:

1 Texto tomado del Condicionado General de un seguro de responsabilidad civil de una compañía aseguradora colombiana, similar a otros donde se contempla la prohibición más no la consecuencia jurídica de su incumplimiento. 
"El Asegurado no puede sin consentimiento previo y escrito de La Compañía aceptar responsabilidades, desistir, transigir, ni hacer cesión de derechos derivados de este seguro, so pena de perder todo derecho bajo esta póliza. ${ }^{2}$

De la simple lectura de la Cláusula resulta claro que para el incumplimiento de esta prohibición se encuentra contemplada la pérdida del derecho a la indemnización. Surge entonces el interrogante: ¿Es esta la consecuencia jurídicamente adecuada para el incumplimiento de esta prohibición?

Existen varios deberes, legales y contractuales, en virtud de los cuales se exige al asegurado abstenerse de determinadas conductas; no obstante, el incumplimiento de estos deberes puede generar distintas consecuencias jurídicas como puede ser la nulidad relativa del contrato, la facultad al asegurador de terminar el contrato, abstenerse de efectuar el pago de la indemnización o descontar de este el monto de los perjuicios que le genere, entre otros.

A pesar de que el contrato de seguro se encuentra ampliamente regulado en el ordenamiento jurídico colombiano, estableciéndose legalmente el contenido y la consecuencia jurídica de varios deberes a cargo del tomador y asegurado, no se encuentra contemplada la prohibición a este de reconocer su responsabilidad y efectuar arreglos con el tercero, como la llamaremos en desarrollo de este trabajo, situación que puede generar discusión en cuanto a la consecuencia jurídica que debe aplicarse al incumplimiento de esta cláusula prohibitiva.

\subsection{Prohibición al Asegurado de reconocer su responsabilidad y realizar acuerdos con el tercero en el Seguro de Responsabilidad Civil en algunas Legislaciones Latinoamericanas.}

A diferencia de lo que ocurre en nuestro ordenamiento, en algunas legislaciones extranjeras esta obligación sí se contempla legalmente, donde encontramos que no existe una postura uniforme respecto de la consecuencia jurídica aplicable a su incumplimiento, como pasa a verse brevemente:

i) Existen ordenamientos donde se contempla la pérdida de derecho a la indemnización como consecuencia jurídica por el incumplimiento de este deber, como ocurre con la legislación chilena:

El artículo 574 de la Ley 20.667 de 2013 en Chile, nos ofrece una referencia clara respecto de la consecuencia jurídica del incumplimiento de la mencionada prohibición, estipulando lo siguiente:

2 Texto tomado del Condicionado General de un seguro de responsabilidad civil de una compañía aseguradora colombiana, similar a otros donde se establece como consecuencia jurídica la pérdida del derecho a recibir el pago de indemnización. 
"Se prohíbe al asegurado aceptar la reclamación contraria o transigir judicial o extrajudicialmente con el tercero afectado, sin previa aceptación del asegurador. El incumplimientodeestaobligación, eximealaseguradordelaobligacióndeindemnizar. No constituye incumplimiento la circunstancia de que el asegurado, en las declaraciones que formule, reconozca hechos verídicos de los que se derive su responsabilidad."

Ciertamente el contenido normativo corresponde al de la cláusula prohibitoria a la que hoy nos referimos, precisando que la consecuencia de su incumplimiento será la liberación al asegurador de cumplir con su obligación indemnizatoria, lo que es igual a la pérdida del derecho a la indemnización desde la perspectiva del asegurado.

ii) Ahora bien, existen otras legislaciones donde a diferencia de lo establecido por la normativa chilena, se contempla una consecuencia jurídica sustancialmente distinta para el incumplimiento de dicha obligación: inoponibilidad al asegurador del acto de reconocimiento de responsabilidad o acuerdo con el tercero. Entre estas legislaciones, podemos encontrar la mexicana y guatemalteca:

En México, el artículo 148 de la Ley Sobre el Contrato de Seguro, publicada el 31 de agosto de 1935 y cuya más reciente modificación se dio mediante el DOF 0404-2013, contempla:

"Ningún reconocimiento de adeudo, transacción o cualquier otro acto jurídico de naturaleza semejante, hecho o concertado sin el consentimiento de la empresa aseguradora, le será oponible. La confesión de la materialidad de un hecho no puede ser asimilada al reconocimiento de una responsabilidad."

En el desarrollo del presente estudio, abordaremos los motivos por los cuales consideramos un acierto de esta norma al contemplar que no le es oponible al asegurador este tipo de reconocimientos por parte del asegurado, pues en lo que respecta al contrato de seguro dicho reconocimiento no constituye prueba suficiente para determinar la procedencia o no del pago de indemnización ni su cuantía.

Guatemala, a su vez, contempla la inoponibilidad de este tipo de reconocimientos por parte del asegurado al asegurador, al mencionar en el artículo 987 del Código de Comercio lo siguiente:

"No será oponible al asegurador que haya contratado un seguro contra la responsabilidad civil, ningún reconocimiento de adeudo, transacción o cualquier otro acto jurídico de naturaleza semejante, hecho o concertado sin su consentimiento."

Podemos observar en el Derecho Comparado que, a pesar de que concuerdan las legislaciones en contemplar la prohibición al asegurado de reconocer su responsabilidad o efectuar acuerdos con el tercero, no existe unanimidad respecto de la consecuencia jurídica aplicable al incumplimiento a dicha prohibición, generando un interrogante respecto a cuál ha de ser el régimen aplicable a dicha cláusula. 
iii) De otra parte, podemos ver que también se ha contemplado la disminución del valor a indemnizar en razón de los perjuicios que no se hubiesen generado de cumplirse con esta prohibición, como ocurre en la legislación Argentina.

El artículo 116 de la Ley 17.418 del 30 de agosto de 1967 en Argentina contempla la prohibición de la siguiente forma:

"Reconocimiento de responsabilidad

El asegurado no puede reconocer su responsabilidad ni celebrar transacción sin anuencia del asegurador. Cuando esos actos se celebren con intervención del asegurador, éste entregará los fondos que correspondan según el contrato en término útil para el cumplimiento diligente de las obligaciones asumidas.

\section{Reconocimiento judicial de hechos}

El asegurador no se libera cuando el asegurado, en la interrogación judicial, reconozca hechos de los que derive su responsabilidad."

En esta norma no se encuentra contemplada la consecuencia jurídica del incumplimiento de la prohibición que establece. Al respecto, Domingo López SAAvedra y CARLOS FACAL Consideran que:

“Este art. 116 no prevé cuál sería la sanción aplicable al supuesto en que el asegurado viole las cargas u obligaciones establecidas en el mismo, lo que dentro del régimen previsto por la Ley de Seguros, parecería dejar un margen de dudas en torno a este tema.

Sin embargo, parece claro que los párrafos segundo y tercero del ya mencionado art. 116 le imponen dos cargas u obligaciones al asegurado que consisten, una en que no puede reconocer su responsabilidad y la otra que tampoco puede transar sin la anuencia del asegurador y en nuestra opinión las mismas tienen la naturaleza jurídica propias de una obligación de salvamento en los términos del art. 72 de dicha ley, lo que significa al asegurado hacer todo lo necesario, en la medida de sus posibilidades, para evitar o disminuir el daño, estableciendo dicho artículo, como lo hemos visto precedentemente, que si el asegurado viola esta carga u obligación mediante dolo o culpa grave, el asegurador quedará liberado de responsabilidad en la medida en que el daño hubiese resultado menor sin esta violación (105). Y en nuestra opinión éste sería el régimen sancionatorio que correspondería aplicar en el caso en que el asegurado incumpliese con las cargas u obligaciones que le impone el ya mencionado art. 116." ${ }^{3}$

Podemos observar que autores argentinos consideran que la consecuencia en su legislación es entonces la disminución del pago de indemnización en proporción a

3 Ver LÓPEZ SAAVEDRA, Domingo M., y FACAL Carlos J.M., "Tratado de Derecho Comercial - Seguros" Ed. La Ley. Buenos Aires, 2010. Págs. 591-592. 
la disminución del daño que se hubiera causado de no incumplirse con dolo o culpa grave con la carga u obligación del asegurado de no reconocer su responsabilidad ni transar con el tercero beneficiario.

Lo anterior cobra una gran importancia teniendo en cuenta que en nuestra legislación no existe referencia expresa a la cláusula en virtud de la cual se prohíbe al asegurado efectuar acuerdos con el tercero y reconocer su responsabilidad, y se ha aceptado en la práctica la aplicación de la pérdida del derecho a la indemnización como consecuencia jurídica, cuya idoneidad jurídica es objeto de nuestro análisis.

\subsection{Contexto Jurídico de la Prohibición al Asegurado de Reconocer su Responsabilidad y Realizar Acuerdos con el Tercero en el Seguro de Responsabilidad Civil.}

Los deberes, -en sentido amplio- del Asegurado, género dentro del cual se encuentra esta prohibición por identidad de sujeto, son clasificables en razón del estado temporal del riesgo, puesto que este elemento natural del contrato cuenta con la entidad suficiente para determinar incluso las conductas que deben asumir las partes y los terceros intervinientes durante las distintas etapas del contrato para su adecuada ejecución.

El riesgo asegurado es el objeto del seguro y, como tal, constituye el elemento esencial más determinante en el contrato, pues no solo permite determinar la especie a la que pertenece un seguro, ${ }^{4}$ sino que incluso es un factor determinante en los demás elementos esenciales, siendo el criterio principal de tasación de la prima, ${ }^{5}$ sobre el cual recae el interés asegurable ${ }^{6}$ y cuya realización da lugar a la obligación condicional del asegurador.

$4 \quad$ P.Ej. Los seguros se clasifican según aspectos del riesgo que se transfiera en Seguros de personas o de daños, reales o patrimoniales, terrestres o marítimos, seguro de responsabilidad civl, salud o de incendio.

5 "Sobre este particular, cumple memorar que la cuantificación de la prima responde -o debe responder-, entre otros factores, a la valoración que hace el asegurador de la probabilidad de ocurrencia del riesgo asegurable y de la intensidad que éste, in casu, pueda llegar a tener, valoración que, se itera, efectúa al momento de contratar, a partir de la información suministrada por el propio candidato a tomador, por lo que resulta incontestable que el precio del seguro está íntimamente ligado, de una u otra forma, con el estado del riesgo, como realidad ontológica. En principio, cuanta más alta sea la probabilidad de siniestro y de extensión de sus efectos, mayor será el valor de la prima; y viceversa. Al fin de cuentas el seguro no es una apuesta." Corte Suprema de Justicia, Sala de Casación Civil y Agraria. Sentencia del 6 de julio de 2007. M.P. Carlos Ignacio Jaramillo Jaramillo. Expediente 359. Refiríéndose al carácter imperativo del artículo 1088 del Código de Comercio, la Cortrema de Justicia manifestó: "Y ello no es más que la consecuencia lógica del interés asegurable como elemento esencial del contrato de seguro, el cual consiste en que el riesgo no se produzca." Corte Suprema de Justicia, Sala de Casación Civil y Agraria. Sentencia del 9 de julio de 2012. M.P. Ariel Salazar Ramírez

7 Art 1054 C.Co.: "Denominase riesgo el suceso incierto que no depende exclusivamente de la voluntad del tomador, del asegurado o del beneficiario, y cuya realización da ori- 
De esta misma forma podemos ver como la obligación principal de ambas partes del contrato se identifican temporalmente, pues la prima pagada por el tomador es devengada por el asegurador en la misma medida en que este asume el riesgo en el tiempo, por lo que el contrato de seguro es un contrato de tracto sucesivo.

La temporalidad del riesgo en el contrato de seguro determina también las conductas que debe asumir el asegurado, siendo entonces el criterio para determinar el régimen de los deberes que en virtud del contrato de seguro surgen para el asegurado según: i) el riesgo esté siendo transferido al asegurador, ii) el riesgo se encuentre siendo asumido por el asegurador, y iii) el riesgo se haya realizado mientras es asumido por el asegurador.

\section{Naturaleza de los deberes del asegurado en razón de su relación temporal con el riesgo asegurable.}

Puesto que la transferencia del riesgo al asegurador es el objeto del contrato de seguro, ${ }^{8}$ es natural que las condiciones contractuales que rigen este negocio jurídico se ajusten a la forma en que el riesgo se presenta a lo largo del contrato, lo que repercute directamente en los distintos efectos jurídicos que incumplimiento de los distintos deberes del asegurado.

Para el asegurado surgen deberes del contrato de seguro incluso cuando aquel no sea parte en este, ${ }^{9}$ puesto que es el asegurado quien ostenta el interés

gen a la obligación del asegurador. Los hechos ciertos, salvo la muerte, y los físicamente imposibles, no constituyen riesgos y son, por lo tanto, extraños al contrato de seguro. Tampoco constituye riesgo la incertidumbre subjetiva respecto de determinado hecho que haya tenido o no cumplimiento."

8 "...Aun cuando el Código de Comercio vigente en el país desde 1972 no contiene en el Título $\mathrm{V}$ de su Libro Cuarto ninguna definición del contrato de seguro, lo cierto es que con apoyo en varias de las disposiciones que de dicho Título hacen parte, y de modo particular en los Arts. 1037, 1045, 1047, 1054, 1066, 1072, 1077 y 1082, bien puede decirse que, en términos generales, es aquél un negocio bilateral, oneroso, aleatorio y de tracto sucesivo por virtud del cual una empresa autorizada para explotar esta actividad, se obliga a cambio de una prestación pecuniaria cierta que se denomina "prima", dentro de los limites pactados y ante la ocurrencia de un acontecimiento incierto cuyo riesgo ha sido objeto de cobertura, a indemnizar al "asegurado" los daños sufridos o, dado el caso, a satisfacer un capital o una renta, según se trate de seguros respecto de intereses sobre cosas, sobre derechos o sobre el patrimonio mismo, supuestos estos en que se les llama de "daños" o de "indemnización efectiva", o bien de seguros sobre las personas cuya función, como se sabe, es la previsión, la capitalización y el ahorro." Ver Corte Suprema de Justicia, Sala de Casación Civil y Agraria. Sentencia del 29 de enero de 1998. M.P. Carlos Esteban Jaramillo Schloss. Expediente 4894. reiterado en Sentencia del 22 de julio de 1999. M.P. Nicolas Bechara Simancas. Expediente 5065.

9 En virtud del art. 1039 C.Co., al asegurado corresponden todas las obligaciones que solo pueda cumplir él, en el evento de ser una persona distinta del tomador. 
asegurable y pude influir en el estado del riesgo y, por tanto, en la ejecución del contrato de seguro.

A pesar de que en la legislación colombiana se prevén distintas disposiciones que se refieren de forma específica las consecuencias de varios de los deberes del asegurado en particular, no es capricho del legislador la asignación de dichos regímenes. En virtud del carácter aleatorio del riesgo tanto en su etapa contractual como precontractual, los efectos del cumplimiento o incumplimiento de los deberes a cargo del asegurado está llamado a generar distintos efectos en razón del estado en que se encuentre el riesgo al momento contractual o precontractual en que el deber se incumpla o incumpla.

Así, encontramos que los deberes del asegurado surten de forma sistemática distintos efectos según repercutan en la decisión del asegurador al i) asumir o no el riesgo, ii) continuar o no asumiendo el riesgo, y iii) afrontar o no las consecuencias económicas de la realización del riesgo.

De esta forma se refleja cómo los criterios temporales para la distinción de la especie y régimen de un deber del asegurado son i) la transferencia del riesgo al asegurador y ii) la ocurrencia del siniestro, motivo por el cual la consecuencia jurídica que consideramos idónea para la prohibición objeto de este escrito es la contemplada para las demás obligaciones que deben cumplirse después de ocurrido el siniestro, la contemplada en el artículo 1078 del Código de Comercio colombiano. ${ }^{10}$ En todo caso, es pertinente realizar unas breves apreciaciones de las demás especies de deberes -en sentido amplio- del asegurado cuya clasificación, cabe reiterar, obedece a la naturaleza misma del contrato de seguro -aleatoriedad del riesgo- y no al capricho del legislador.

\subsection{Deberes del Asegurado al Momento de Transferir el Riesgo al Asegurador.}

El contrato de seguro, al ser consensual, nace a la vida jurídica en el momento en que las partes llegan a un acuerdo respecto de los elementos esenciales contemplados en el artículo 1045 del Código de Comercio, el riesgo entre ellos, ${ }^{11}$ Motivo por el cual es

10 "Si el asegurado o el beneficiario incumplieren las obligaciones que les corresponden en caso de siniestro, el asegurador sólo podrá deducir de la indemnización el valor de los perjuicios que le cause dicho incumplimiento.

La mala fe del asegurado o del beneficiario en la reclamación o comprobación del derecho al pago de determinado siniestro, causará la pérdida de tal derecho."

11 "En efecto, aún cuando en el derecho colombiano, por decenios, reinó la visión formalista del contrato de seguro, encaminada a restringir el haz de posibilidades en punto tocante con su perfeccionamiento, finalmente se impuso la tesitura de la libertad de forma, con arreglo a la cual los futuros contratantes podrán expresar su voluntad sin ataduras o formalidades, en concordancia con el artículo 824 del Código de Comercio, fiel reflejo del genuino espíritu que orientó la redacción de la codificación mercantil que nos gobierna, el mismo que, en general, campea en el derecho comparado, tanto más ahora, cuando la globalización, la apertura y la internacionalización se enseñorean en el concierto mundial. 
importante que el asegurador conozca las condiciones en que se encuentra el riesgo y los factores que lo determinan al momento de consentir en la asunción del riesgo y realizar la tasación de la prima.

Esta situación representa deberes -en sentido amplio- ${ }^{12}$ para el asegurado encaminados a que el asegurador conozca cuál el estado real en que se encuentra el riesgo y cuáles son los factores determinantes en su probabilidad de realización, así como el alcance económico que de esta se pueda desprender, pues a partir del análisis que efectúe al respecto consentirá en celebrar o no el contrato de seguro. ${ }^{13}$

Dado que cumplen con la finalidad de información al asegurador al momento en que este manifiesta su voluntad en celebrar el contrato de seguro, la consecuencia jurídica que les es natural al incumplimiento de dicha especie de deberes es la Nulidad Relativa del contrato, teniendo en cuenta la rigidez con que el asegurado debe suministrar la información veraz que conozca en virtud de la ubérrima fides. ${ }^{14}$

Ello explica, como telón de fondo, la adopción de los artículos 1036 y 1046 del Código de Comercio, en su nueva versión, que no fueron adoptados inopinadamente, o sin ninguna argumentación, según se desprende de los diversos debates parlamentarios que, en su oportunidad, les dieron carta de ciudadanía, en atención a la ley 389 de 1997." JARAMILLO JARAMILLO, Carlos Ignacio. DERECHO DE SEGUROS. Estudios y Escritos Jurídicos. Tomo II El Contrato de Seguro, Teoría General del Contrato. Editorial Temis. 2011. Bogotá D.C. Pág. 19.

12 Podemos observar que la declaración del estado del riesgo es una obligación para el tomador/asegurado (art. 1058 C.Co.), mientras que la garantía de afirmar o negar la existencia de determinada situación de hecho es definida legalmente como una promesa (art. 1060) y la mala fe en la contratación que dé lugar a coexistencia, pese a ser una exigencia de buena fe (art. 1092)

13 "El artículo 1058 del Código de Comercio, resume una buena experiencia de derecho comparado sobre la materia y adopta sin dificultades la tendencia tradicional de ubicar el tema dentro de la teoría de los vicios del consentimiento, defendiendo el ámbito del deber de información del tomador a las circunstancias que rodean el riesgo y determinan su intensidad, y sancionando el incumplimiento trascendente del deber de información del tomador con la nulidad del contrato de seguro, asociándolo claramente al vicio que el mismo genera en la manifestación de voluntad del asegurado." ORDÓÑEZ ORDÓÑEZ, Andrés. LOS DEBERES RECÍPROCOS DE INFORMACIÓN EN EL CONTRATO DE SEGURO. En Revista Ibero-Latinoamericana de Seguros No. 22. Pontificia Universidad Javeriana. 2005. Pág. 14.

14 Código Civil, Artículo 1510: "El error de hecho vicia el consentimiento cuando recae sobre la especie de acto o contrato que se ejecuta o celebra, como si una de las partes entendiese empréstito y la otra donación; o sobre la identidad de la cosa específica de que se trata, como si en el contrato de venta el vendedor entendiese vender cierta cosa determinada, y el comprador entendiese comprar otra." 


\subsection{Deberes (Obligaciones) del Asegurado Durante la Asunción del Riesgo por parte del Asegurador.}

Una vez se ha celebrado el contrato de seguro y desde que este ha iniciado su vigencia técnica, ${ }^{15}$ el riesgo asegurado corre a cargo del asegurador, quien consintió en asumirlo en razón del estado en que el asegurado le informó que se encontraba.

De esta forma, encontramos que es natural que las obligaciones que debe asumir el asegurado durante la asunción del riesgo por parte del asegurador se encuentren encaminadas a que el riesgo se mantenga en las mismas condiciones en que el asegurador acordó asumirlo y, en caso de haber modificaciones en su estado, que el asegurador tenga conocimiento de dichos cambios, pues el estado en que se encuentra el riesgo trasladado al asegurador es determinante en la ejecución del contrato de seguro.

En virtud de lo anterior, con estas obligaciones se da continuidad a la finalidad que persiguen los deberes del asegurado al momento de celebración del contrato: el conocimiento que el asegurador tenga sobre el estado del riesgo que asume. Por ello, es natural que el incumplimiento de los deberes/obligaciones ${ }^{16}$ del asegurado durante la asunción del riesgo por el asegurador dé lugar a la finalización de dicho traslado del riesgo, la terminación del contrato de seguro. ${ }^{17}$

15 Al respecto, el artículo 1057 del Código de Comercio contempla: "En defecto de estipulación o de norma legal, los riesgos principiarán a correr por cuenta del asegurador a la hora veinticuatro del día en que se perfeccione el contrato."

16 Los deberes del asegurado en esta etapa contractual son la conservación del estado del riesgo y notificación de cambios (art. 1060 C.Co.), la garantía en virtud de la cual el asegurado se obliga a hacer o no determinada cosa o a cumplir determinada exigencia (art. 1061 C.Co.), y el aviso al asegurador de la coexistencia de seguros (art. 1093 C.Co.); todos los cuales corresponden a obligaciones a cargo del asegurado.

17 P.ej. La Corte Suprema de Justicia ha señalado: "En efecto, en relación con el apellidado estado del riesgo, ab initio, es necesario distinguir dos fases claramente identificadas en el derecho comparado y también en la legislación comercial patria: a) La primera, vinculada a la formación del contrato, durante la cual el tomador tiene "la obligación" - preferiblemente carga, según concepto precisado en sentencia de 30 de septiembre de 2004, exp. 7142- de declarar sinceramente la situación en que se encuentra el riesgo que se pretende amparar... // b) La segunda de las fases ya aludidas, relativa al desenvolvimiento del negocio aseguraticio, previamente concertado o perfeccionado, ello es basilar, le impone al tomador y, dado el caso, al asegurado, la carga de mantener el riesgo en las condiciones en que se aseguró primigeniamente, hipótesis en la cual deberán notificarse al asegurador los hechos o circunstancias relevantes, imprevisibles y sobrevinientes que de una u otra manera alteren el mencionado estado del riesgo (art. 1060, ib,). De allí que justamente, por tratarse de un deber de prestación que concierne al desarrollo del contrato (etapa de ejecución negocial), su quebrantamiento genera la terminación del seguro, como efecto propio de los negocios jurídicos de duración y, más concretamente, de tracto sucesivo (art. 1036 C. de Co.)" Ver Corte Suprema de Justicia, Sala de Casación Civil y Agraria. Sentencia del 6 de julio de 2007. M.P. Carlos Ignacio Jaramillo Jaramillo. Expediente 359. 


\subsection{Deberes del Asegurado al Realizarse el riesgo.}

En tanto no se haya realizado el riesgo, la ejecución del contrato de seguro se da de una forma uniforme en la medida que las conductas esperadas de las partes y terceros intervinientes es igual desde que se celebró el contrato, donde el asegurador está asumiendo el riesgo y el asegurado debe cumplir con obligaciones encaminados a que el riesgo se mantenga en las condiciones en que se trasladó al asegurador y, en todo caso, que éste conozca de las modificaciones que el riesgo pueda sufrir, lo que le es común a casi todos los contratos de seguro, teniendo en cuenta las particularidades de cada uno de ellos, con dos puntuales excepciones: Seguros de Vida ${ }^{18}$ y Seguros de Cumplimiento. ${ }^{19}$ No obstante, si el riesgo se realiza durante la vigencia del contrato, la conducta contractual cambia sustancialmente tanto para el asegurador como para el asegurado/beneficiario.

Al realizarse el riesgo, se cumple la condición a la que se encuentra sujeta la obligación condicional del asegurador, surgiendo también obligaciones en cabeza del asegurado cuya naturaleza jurídica se define a partir de la realización del riesgo y la consecuente obligación del asegurador de efectuar el pago de la indemnización. ${ }^{20}$

Es preciso mencionar que en el seguro de responsabilidad civil el rol de beneficiario se encuentra en cabeza de una persona distinta del asegurado, lo que no ocurre en las demás especies de seguros. Esta distinción entre asegurado y beneficiario se refleja en que la carga probatoria contenida en el artículo $1077^{21}$ le es impuesta también al

18 El Código de Comercio, en su artículo 1159 prohíbe de forma expresa al asegurador revocar el contrato de seguro en ningún caso, entendiendo la revocación como la terminación unilateral del contrato. Comparar con MOLINA MORALES, Ranfel. "La Terminación Unilateral del Contrato por Incumplimiento" en Revista de Derecho Privado Externado 17-2009. Pág. 85.

19 El seguro de cumplimiento en favor de entidades estatales es irrevocable en virtud del artículo 7 de la Ley 1150 de 2007; interpretación que, por la naturaleza del riesgo asegurado, le ha sido extendida al seguro de cumplimiento en favor de particulares. Comparar con Superintendencia Financiera de Colombia. Concepto 2007012879-001 del 9 de mayo de 2007.

20 "El hecho dañoso inicial (...) ipuede constituir el siniestro? Efectivamente lo es. Desde el punto de vista meramente material y hasta meramente económico, el momento en que ocurre el siniestro es asimismo el momento en que ocurre el siniestro de responsabilidad civil. Si se toma en cuenta, una vez más, que se está ante lo que es una moneda con dos caras, uno podría decir que en una de sus caras es la causa de la que emerge la responsabilidad pero además, en su otra cara, tiene un efecto inmediato que refleja e implica la potencialidad de un daño eventual sobre el patrimonio del autor, en consecuencia, del eventual asegurado." RIPPE, Siegbert. LA CONFIGURACIÓN DEL SINIESTRO EN EL SEGURO DE RESPONSABILIDAD CIVIL. En Revista Ibero-Latinoamericana de Seguros. No. 21. 2004. Pág. 35.

21 "Corresponderá al asegurado demostrar la ocurrencia del siniestro, así como la cuantía de la pérdida, si fuere el caso." 
tercero beneficiario, pues es él quien debe acreditar los perjuicios que sufrió por la ocurrencia del siniestro. ${ }^{22}$

En todo caso, la demostración de ocurrencia del siniestro y cuantía de la pérdida son cargas que también quedan en cabeza del asegurado pues el tercero puede reclamarle a él directamente el pago de indemnización, caso en el cual el asegurado se legitima para reclamar el pago de indemnización a la compañía de seguro. ${ }^{23}$

En nuestra opinión, el incumplimiento de esta carga en cabeza del asegurado no representa ninguna injerencia en la existencia de la obligación condicional del asegurador, dado que la condición suspensiva se encuentra cumplida y la obligación del asegurador nace desde este mismo momento. ${ }^{24}$ De hecho, el cumplimiento de esta carga da lugar a efectos jurídicos específicos como son el mérito ejecutivo de la póliza, ${ }^{25}$ y la constitución en mora del asegurador, lo que equivale a la exigibilidad de la obligación. ${ }^{26}$

22 El tercero puede reclamar la indemnización al responsable del daño (asegurado), como también puede hacerlo el tercero en virtud de la acción directa contenida en el artículo 1133 del Código de Comercio, acreditar la ocurrencia y cuantía del siniestro en los términos del artículo 1077 del Código de Comercio. No obstante, cuando el tercero le reclama al asegurado, éste se legitima para reclamar al asegurador el pago de la indemnización del siniestro.

23 "Siguiendo los artículos 1077 y 1080 del Código de Comercio, la víctima o el asegurado tienen la posibilidad de buscar el pago de la indemnización mediante la presentación de una reclamación, la cual debe cumplir dos requisitos: probar el siniestro y probar la cuantía de la pérdida. En el terreno del seguro de responsabilidad hemos dicho que este cometido no es fácil." Ver DIAZ-GRANADOS, Juan Manuel. El Seguro de Responsabilidad. Pág. 246.

24 La Corte Suprema de Justicia ha manifestado que "Aunque la realización del siniestro actualiza, como se dijo, la obligación del asegurador, su exigibilidad sólo se produce con la expiración del plazo de un mes que legalmente se le concede para atenderla artículo 1080 del Código de Comercio-, término que corre a partir del momento en que el asegurado, o el beneficiario, si es el caso, satisface la carga impuesta por el artículo 1077 de la citada obra, o sea, acreditar tanto la ocurrencia del siniestro, como la cuantía de la pérdida sufrida por causa del suceso, si a ello hubiere lugar." Corte Suprema de Justicia, Sala de Casación Civil y Agraria. Sentencia del 29 de noviembre de 2009. M.P. Jaime Alberto Arrubla Paucar. Expediente 9730-0351.

Al respecto, debemos señalar que es desde la ocurrencia del hecho que compromete la responsabilidad civil del asegurado que inicia el término de prescripción para el beneficiario, haciéndose entones exigible desde ese momento la obligación condicional del asegurador. Ocurre una particularidad con la acción del asegurado, puesto que la prescripción para él inicia desde el momento en que el tercero le reclama (art. 1131), lo cual responde al hecho de que antes de ello no existe una pérdida indemnizable en el patrimonio del asegurado, pues no se ha visto afectado ante la ausencia de reclamación por parte del tercero.

25 Art. 1053 del Código de Comercio

26 Art. 1080 del Código de Comercio 
Es por lo anterior, que el asegurado o el beneficiario puede iniciar un proceso ordinario en contra de la compañía de seguros con el fin de obtener el pago de la indemnización así no haya efectuado una previa reclamación extrajudicial al asegurador. ${ }^{27}$ En este caso, la carga del asegurado se debe cumplir a través de las pruebas en el proceso, pues constituye también la acreditación de la exigibilidad de la obligación cuyo pago reclama ante el juez.

Por lo anterior debemos mencionar que el asegurado y el beneficiario nunca se liberan de su carga de acreditar ante el asegurador la ocurrencia del siniestro y la cuantía de la pérdida, judicial o extrajudicialmente, puesto que es a partir del cumplimiento de esta carga probatoria que el plazo para que el asegurador efectúe el pago la indemnización a que se obligó en virtud del contrato de seguro. ${ }^{28}$

Habiendo advertido con anterioridad que la cláusula que prohíbe al asegurado realizar acuerdos o reconocer su responsabilidad constituye un deber del asegurado

27 "sobre el asegurado... gravita el onus probandi de la ocurrencia del siniestro, la existencia y cuantía de la lesión, correspondiendo al asegurador probar «los hechos o circunstancias excluyentes de su responsabilidad» (artículo 1757 Código Civil, 177 Código de Procedimiento Civil y 1077 Código de Comercio)... En lo atañedero a la demostración del siniestro, el daño y la cuantía de la pérdida, al tenor de los artículos 1077 y 1080 del Código de Comercio, el asegurado puede acreditar en forma judicial o extrajudicial su derecho, siendo admisible todo medio probatorio lícito e idóneo, conducente, eficaz y con aptitud para suministrar certeza a propósito, en cuanto, el legislador no establece restricción alguna y a tono con los cambios sensibles del tráfico jurídico de las últimas décadas, incluso admite la relevancia jurídica del dato electrónico no sólo respecto del comercio y la contratación sino en materia probatoria (Ley 527 de 1999, arts. 95 ss. de la Ley 270 de 1996)...", Ver Corte Suprema de Justicia, Sala de Casación Civil y Agraria. Sentencia del 6 de mayo de 2009. M.P. William Namén Vargas. Expediente 083.

De lo anterior, cabe concluir que la carga establecida en el artículo 1077 del Código de Comercio a cargo del asegurado únicamente cumple un propósito probatorio, nunca un requisito de exigibilidad de la obligación del asegurador.

28 “(...)En cuanto refiere al argumento expuesto en la alzada, según el cual es a la aseguradora a quien correspondía demostrar la extensión material del daño y su estimación económica, por ser quien de acuerdo con la costumbre mercantil "efectúa la inspección del siniestro y designa los ajustadores, que son las personas expertas y quienes determinan si hubo o no siniestro, y establecen si existió éste, el valor que debe reconocer y pagar la aseguradora al beneficiario de la póliza", hay que decir que, en primera medida, la costumbre mercantil que invoca el apelante no aparece probada en el expediente y, en todo caso, el hecho de que la aseguradora designe el ajustador o haga inspecciones para verificar la ocurrencia del siniestro, no exime al asegurado de demostrar los supuestos previstos en el artículo 1077 del Código de Comercio. // A la postre, la norma en mención no tiene excepciones cuando se trata del seguro de daños y, además, debe decirse que las labores de ajuste y verificación que realizan el ajustador y la aseguradora, son actividades que en manera alguna sustituyen o modifican la carga demostrativa que pende sobre el asegurado, quien es el llamado a saber hasta dónde llega el perjuicio y cuál es su quantum." Corte Suprema de Justicia, Sala de Casación Civil y Agraria. Sentencia del 23 de noviembre de 2010. M.P. Edgardo Villamil Portilla. Expediente 198. 
relacionada con el riesgo realizado dado que el reconocimiento de responsabilidad o el acuerdo que se prohíbe se refieren a un siniestro acaecido, es preciso aclarar que esta obligación le es propia particularmente al contrato de seguro de responsabilidad civil, dada la peculiaridad que se presenta en esta especie de seguros al ser distinto el asegurado del beneficiario. ${ }^{29}$

Al encontrarnos ante la especie de obligaciones dentro de las que se encuentra la prohibición objeto de estudio, es preciso referirnos a la naturaleza jurídica de esta especie de deberes del asegurado mediante el análisis de las distintas obligaciones que la componen, no sin antes precisar la finalidad que en general persiguen.

Hemos observado que los deberes del asegurado al momento de celebrar el contrato de seguro y durante su vigencia sin ocurrencia del siniestro se encuentran encaminados que el asegurador tenga conocimiento cierto respecto de las condiciones en que se encuentre riesgo que asume. De la misma forma, una vez se ha realizado el riesgo, es necesario que el asegurador conozca las condiciones y efectos de su realización, pues ello delimita el alcance de la obligación indemnizatoria a su cargo, la cual debe corresponder estrictamente al riesgo que una vez delimitado fue asumido por él. En otras palabras, las obligaciones a cargo del asegurado con posterioridad a la ocurrencia del siniestro se encuentran encaminadas a la correcta determinación de la cuantía indemnizable a la luz del contrato de seguro, en atención a la delimitación de los riesgos transferidos al asegurador y, en todo caso, desarrollando el principio indemnizatorio en adición a los fines particulares que cada obligación puntualmente persiga.

\section{Obligación de evitar que el siniestro se extienda y propague:}

Toda vez que al realizarse el riesgo asegurado surge la obligación condicional del asegurador consistente en indemnizar al asegurado o beneficiario por las pérdidas generadas por el siniestro, la extensión y propagación del mismo que no se eviten por parte del asegurado, pudiendo evitarlas, implicaría que las pérdidas asumidas por el asegurador sean mayores a las que asumiría de haber sido diligente el asegurado con el cumplimiento de su obligación.

Cabe recordar que las obligaciones a cargo del asegurado antes de la realización del riesgo se encuentran encaminadas a que el riesgo se mantenga en el estado en que fue transferido al asegurador. De esta misma forma, las obligaciones posteriores a la realización del riesgo pretenden que este riesgo -ahora acaecido, cierto e indemnizable- se mantenga en las mismas condiciones en que mantendría en el evento de

29 La característica de ser distintos el asegurado del beneficiario también la comparten los seguros de vida, toda vez que la realización del riesgo asegurado es el fallecimiento del asegurado mismo. No obstante y por obvias razones, la prohibición de reconocer responsabilidad o realizar acuerdos con el tercero/beneficiario no le es natural a dicha especie de seguros. 
no haberse transferido al asegurador, exigiéndose entonces al asegurado una conducta diligente ante el siniestro ocurrido.

De esta forma se establece la obligación de evitar la extensión y propagación del siniestro, puesto que no concordaría con el carácter indemnizatorio del contrato del seguro que el asegurador asumiera los daños que pudieron evitarse por parte del asegurado de haber actuado diligentemente ante la ocurrencia del siniestro. Al respecto el artículo 1074 del Código de Comercio contempla:

Art. 1074. C.Co. "Ocurrido el siniestro, el asegurado estará obligado a evitar su extensión y propagación, y a proveer al salvamento de las cosas aseguradas.

El asegurador se hará cargo, dentro de las normas que regulan el importe de la indemnización, de los gastos razonables en que incurra el asegurado en cumplimiento de tales obligaciones."

Debemos tener presente que la misma norma que contempla esta obligación señala en su inciso segundo contempla una norma indemnizatoria para los gastos en que incurra el asegurado al cumplir con su obligación, pues dichos gastos constituyen para el asegurado que obró diligentemente un Daño Emergente derivado de la ocurrencia del siniestro y, que debe ser asumido por el asegurador por el carácter indemnizatorio del pago con que satisfaga su obligación condicional.

Dado que esta obligación resulta en extremo casuista por requerir de un análisis fáctico del siniestro, según el tipo de riesgo que se ampara y la forma particular en que se dé su realización, las acciones razonables que pueda tomar el asegurado para evitar la extensión del mismo no son estáticas, sino que varían según el caso y su cumplimiento debe analizarse en cada caso con base en criterios como la buena fe y deber de diligencia del asegurado.

De otra parte, puesto que esta obligación define y delimita el importe de la indemnización al valor estricto de la realización del siniestro, su incumplimiento debe acarrear para el asegurado la asunción del costo de los daños derivados de su inacción ante el siniestro ocurrido, pues dicha situación no corresponde a la realización de riesgos asegurados en el contrato de seguro y, por ende, no constituyen rubros indemnizables en virtud del mismo.

\section{Obligación de Dar Aviso al Asegurador de la Ocurrencia del Siniestro}

Entraña esta obligación la importancia de que el asegurador conozca oportunamente de la ocurrencia del siniestro, puesto que como profesional en la actividad puede intervenir en operaciones de salvamento, comprobación del siniestro e, incluso, evitando la propagación y extensión de este.

De la lectura del artículo 1075 del Código de Comercio, resulta claro que la obligación pretende que el asegurador tenga conocimiento oportuno de la ocurrencia del 
siniestro, ${ }^{30}$ porque gracias a ello puede desplegar actividades que sin perjuicio de las cargas y obligaciones del asegurado, le permitan determinar y delimitar la obligación condicional a su cargo. Cobra más fuerza este análisis al observar que la norma impide al asegurador alegar el incumplimiento de dicha obligación cuando dentro del término de oportunidad para el aviso, establecido legal o contractualmente, interviene en las operaciones de salvamento y comprobación del siniestro; bien sea directamente o a través de terceros.

Como el cumplimiento de esta obligación permite al asegurador tomar medidas oportunas frente a la ocurrencia del siniestro, es natural que el incumplirla dé lugar a que el asegurador se abstenga indemnizar los daños y perjuicios que hubiesen podido evitarse por estas medidas, puesto que a su vez constituirían perjuicios para el asegurador, quien no pudo tomar medidas oportunas frente a la ocurrencia del siniestro.

\section{Obligación de Proveer al Salvamento de las Cosas Aseguradas}

El artículo 1074 del Código de Comercio dispone esta obligación al asegurado o el beneficiario, según sean o no la misma persona. Consideramos que esta obligación por su objeto recae en cabeza de la persona que ostente la calidad de beneficiario, indistintamente de que coincida o no con la calidad de asegurado. Lo anterior, teniendo en cuenta que el salvamento solo puede ser proveído por el acreedor final de la indemnización. De esta forma, en los seguros reales el asegurado debe cumplir con esta obligación, pero ello obedece a que también ostenta la calidad de beneficiario.

En el seguro patrimonial de responsabilidad civil, esta obligación se encuentra a cargo del beneficiario, pues es él a quien se pretende indemnizar y quien ostentaría la propiedad de los bienes objeto del salvamento. ${ }^{31}$ Aplica esta obligación para cuando hay daños materiales derivados del siniestro que no necesariamente implican la destrucción total del bien, pero el asegurador opte por pagar el valor real del bien aun siendo superior al valor de la pérdida.

Al subsistir los bienes afectados por el siniestro, el efectuar una indemnización mediante el pago del valor real constituiría un enriquecimiento en cabeza del asegurado, puesto que los bienes subsistentes al siniestro continuarían constituyendo un activo en su patrimonio. ${ }^{32}$

Por lo tanto, consideramos que es natural que la consecuencia jurídica del incumplimiento de esta obligación, por serle natural a esta especie de obligaciones

30 Artículo 1075 del Código de Comercio.

31 Art. 1041 C.Co. "Las obligaciones que en este título se imponen al asegurado, se entenderán a cargo del tomador o beneficiario cuando sean estas personas las que estén en posibilidad de cumplirlas.",

32 Artículo 1074 del Código de Comercio. 
con posterioridad al siniestro salvaguarde al principio indemnizatorio permitiendo al asegurador deducir del pago de la indemnización el valor de los bienes asegurados subsistentes al siniestro que no le sean proveídos en calidad de salvamento, de forma que no se constituya un enriquecimiento injustificado en cabeza del beneficiario.

\section{Obligación de procurar la subrogación del asegurador, incluyendo el no renunciar a sus derechos frente a terceros responsables por el siniestro.}

Esta obligación, en principio, no le es aplicable al asegurado en el seguro de responsabilidad civil pues en este seguro el responsable del siniestro es el mismo asegurado. Incluso en el evento de existir concurrencia de culpas en el siniestro, la obligación indemnizatoria del asegurador se encuentra delimitada exclusivamente por la responsabilidad del asegurado, por lo que únicamente ha de pagar la proporción de las pérdidas del siniestro correspondientes a la participación de la responsabilidad del asegurado al generarse.

En efecto, la subrogación del asegurador se encuentra contemplada en el art. 1096 del Código de Comercio ${ }^{33}$ dentro de los principios comunes a los seguros de daños en el Capítulo concerniente a esta especie de seguros, ${ }^{34}$ donde el asegurado es el mismo beneficiario del seguro en los seguros reales, evento en el que los daños que el asegurador paga pudieron haber sido ocasionados por culpa de un tercero, caso en el que el asegurador se subroga en los derechos del asegurado en calidad de víctima del siniestro que compromete la responsabilidad civil de un tercero.

No obstante, es factible que la subrogación del asegurador se dé en virtud del pago de la indemnización en seguros de responsabilidad civil, circunstancia que se da en el marco de la solidaridad pasiva del asegurado con terceros, derivada de la responsabilidad por hecho ajeno. ${ }^{35}$

En el transporte marítimo encontramos un claro ejemplo de la responsabilidad solidaria, pues podemos ver que la misma Ley establece que el armador del buque responde por las indemnizaciones debidas o pérdidas causadas por culpa del capitán, de la tripulación, del práctico o de cualquiera otra persona al servicio de la nave. ${ }^{36}$ Así mismo, el agente marítimo es solidariamente responsable por toda clase de obligaciones que el armador o el capitán contraigan en el país en razón de la nave agenciada. ${ }^{37}$

33 Art. 1096 C.Co.: "El asegurador que pague una indemnización se subrogará, por ministerio de la ley, y hasta concurrencia de su importe, en los derechos del asegurado contra las personas responsables del siniestro. (...)"

34 Título V 'Del contrato de Seguro', Capítulo II 'Seguros de daños', Sección I 'Principios comunes a los seguros de daños'.

35 Art. 2347 C.C.: "Toda persona es responsable, no sólo de sus propias acciones para el efecto de indemnizar el daño, sino del hecho de aquellos que estuvieren a su cuidado."

36 Art. 1481 C.Co.

37 Art. 1492 C.Co. 
Si bien la responsabilidad del armador se ampara mutualmente por un club $\mathrm{P} \& \mathrm{I}^{38}$ el agente marítimo nacional si asegura su responsabilidad civil con aseguradores nacionales, quienes podrán subrogarse en los derechos del agente marítimo en contra de quien sea el directamente responsable por el siniestro (armador o capitán), en virtud del artículo 1579 del Código Civil. ${ }^{39}$

De esta forma, podrá el asegurador que asume la responsabilidad civil del agente marítimo subrogarse hasta por el monto indemnizado al tercero beneficiario en contra del armador, el capitán e, incluso, del club P\&I que les ampara, al igual que en cualquier otro evento en que el asegurado sea responsable por un hecho ajeno.

Ahora bien, la obligación del asegurado de procurar la subrogación del asegurador nos ofrece un claro ejemplo desarrollo del principio indemnizatorio a través de las obligaciones a cargo del asegurado: La subrogación contemplada en el artículo 1096, se da excepcionalmente por ministerio de la Ley, puesto que no parte del supuesto de pago de una deuda ajena, sino de una propia derivada del contrato de seguro. ${ }^{40} \mathrm{De}$ esta forma, la subrogación encuentra sus límites en el valor pagado al asegurado que efectivamente constituya indemnización a la luz del contrato de seguro, ${ }^{41}$ de manera que todo pago que corresponda a algún rubro que no constituya indemnización tampoco será objeto de subrogación.

38 El Club P\&I (Protection \& Indemnity Club) es un Fondo mutual en el que participan distintas navieras con el fin de precaver los daños que comprometan su responsabilidad civil frente a propietarios de la carga, otros buques y afectaciones ambientales, entre otros riesgos. Normalmente están constituidas en Londres y no celebran propiamente contratos de seguro, por lo que no les es aplicable la legislación colombiana concerniente a dicho contrato.

39 Art. 1579 C.C.: "El deudor solidario que ha pagado la deuda o la ha extinguido por alguno de los medios equivalentes al pago, queda subrogado en la acción del acreedor con todos sus privilegios y seguridades, pero limitada respecto de cada uno de los codeudores a la parte o cuota que tenga este codeudor en la deuda.

Si el negocio para el cual ha sido contraída la obligación solidaria, concernía solamente a alguno o algunos de los deudores solidarios, serán estos responsables entre sí, según las partes o cuotas que le correspondan en la deuda, y los otros codeudores serán considerados como fiadores.

La parte o cuota del codeudor insolvente se reparte entre todos los otros a prorrata de las suyas, comprendidos aun aquellos a quienes el acreedor haya exonerado de la solidaridad."

40 "...la subrogación prevista en el artículo 1096 es, en cierta forma, sui generis, puesto que no tiene como presupuesto el pago de una deuda ajena, esto es, la del tercero responsable, sino, de una propia por la cual ha obtenido como contraprestación el pago de una prima, peculiar característica que llevó al legislador a señalarle el límite que le designó y que una vez cubierta por el responsable implica un pago total y válido al asegurador." Corte Suprema de Justicia, Sala de Casación Civil y Agraria. Sentencia del 13 de octubre de 1995. M.P. Hector Marín Naranjo. Expediente 3986.

41 Comparar con art. 1096. C.Co.: "El asegurador que pague una indemnización se subrogará (...) hasta concurrencia de su importe, en los derechos del asegurado (...)" 
Lo anterior nos permite profundizar en una especial particularidad relevante para efectos de la prohibición al asegurado de reconocer su responsabilidad y realizar acuerdos con el tercero: la disponibilidad del derecho a ser indemnizado.

En efecto, el acreedor de una obligación indemnizatoria tiene la facultad de renunciar al derecho que para él representa dicha obligación, efectuar conciliaciones, transacciones y, en general, disponer de él; situación de suma relevancia para el asegurador cuyo patrimonio se verá afectado por la decisión que tomen el tercero acreedor y el asegurado deudor respecto de la relación de responsabilidad civil originada en el siniestro, puesto que puede implicar una disposición del derecho que ostente el tercero a ser indemnizado.

Esta obligación de procurar el ejercicio de la subrogación tiene la particularidad de encontrar distintas consecuencias legalmente contempladas, puesto que el Código de Comercio prevé de forma separada dos eventos que, en el fondo, entraña la misma situación:

El artículo 1098 contempla la obligación del asegurado de hacer todo lo que esté a su alcance para permitirle al asegurador ejercer sus derechos, lo que no es otra cosa que la obligación de mantener incólume su derecho a resarcimiento a cargo del tercero, pues en tal derecho se subrogará el asegurador hasta el monto de la indemnización que este pague. ${ }^{42}$

El incumplimiento de esta obligación generará un perjuicio al asegurador en la medida en que no pueda ejercer la subrogación, pudiendo deducir dicho perjuicio del monto a indemnizar en virtud del contrato de seguro, lo que se refleja en la remisión expresa que hace el inciso segundo del artículo mencionado al artículo 1078 del Código de Comercio.

Por su parte, el artículo 1097 contempla la pérdida del derecho a indemnización cuando el asegurado renuncia a sus derechos frente al tercero responsable, lo cual obedece a la misma limitación gradual indemnizatoria que ya mencionamos, pero referida puntualmente al evento en que el asegurado impide por completo la subrogación del asegurador, de manera que todo pago que el asegurador haga al asegurado constituirá un perjuicio para aquél y, por tanto, podrá deducirlo de la indemnización en la misma proporción.

Podemos concluir que la disposición de derechos que haga el asegurado frente al tercero, repercuten directamente en su derecho frente al asegurador, pues a pesar de que la obligación del asegurador encuentre su fuente en un caso del daño y en el otro del contrato de seguro, el derecho se encuentra sujeto al principio indemnizatorio en que se basa la obligación condicional del asegurador. 
En el seguro de responsabilidad civil, el reconocimiento de responsabilidad del asegurado o su acuerdo con el tercero puede constituir una renuncia a los derechos de aquél contra éste, ${ }^{43}$ circunstancia en la que no hay lugar a indemnización, pero es en en razón de la renuncia misma que el acreedor hace respecto de la obligación indemnizatoria en su favor, no como 'consecuencia del/sanción al' simple hecho del reconocimiento de responsabilidad o el acuerdo per se.

\section{Obligación de Declarar Seguros Coexistentes.}

Esta obligación tiene la particularidad de encontrarse establecida para el asegurado durante todas las etapas del contrato de seguro, sobre lo cual se ha pronunciado el doctor Hernán Fabio López, señalando:

"La razón de ser de estas dos normas (Arts. 1076 y 1093 del C.Co.)-que desafortunadamente no se complementan sino que, al contrario, son contradictorias porque dan pie para establecer el cumplimiento de un deber en momentos por entero diferentes, ya que conforme a una disposición es en el momento de avisar el siniestro y según la otra es en el plazo de diez días siguientes a su contratación es la de permitir al asegurador tomar las medidas pertinentes en orden a evitar que respecto del mismo objeto existan seguros que superen el valor de él (lo cual puede ser aliciente para provocar, o al menos no impedir, la ocurrencia de siniestros) y establecer la forma como se debe pagar la indemnización haciendo aplicables las reglas del coaseguro frente al principio indemnizatorio, es decir, para que cada asegurador cancele lo que proporcionalmente le corresponda de manera que el asegurado nunca pueda encontrar en el seguro una fuente de lucro. " 44

En nuestra opinión, la existencia de normas que regulan esta obligación para distintos momentos en el contrato de seguro, incluyendo también el art. 1092 del C.Co., no constituye una contradicción sino que debe apreciarse desde la perspectiva de la existencia de dos seguros y bajo la premisa de que uno de ellos se celebra antes que otro, siendo la celebración del segundo contrato el momento en que se configura la coexistencia de seguros. Debemos tener en cuenta que la coexistencia de seguros se da al momento de celebrarse el segundo contrato de seguro, por lo que el primer contrato ya se encuentra en un momento distinto y ambas circunstancias se deben regular por la Ley.

Cronológicamente, podemos mencionar que el primer contrato de seguro se celebró y ya se encuentra generando efectos jurídicos para el momento en que se toma el segundo contrato de seguro, por lo que al primer contrato le ha de ser aplicable la terminación del contrato por la falta de aviso prevista en el art. 1093 C.Co., mientras

43 P.ej. El agente marítimo/asegurado puede renunciar a sus derechos en contra del capitán o el armador responsable de la ocurrencia del siniestro.

44 Ver LÓPEZ BLANCO, Hernán Fabio. COMENTARIOS AL CONTRATO DE SEGURO. Dupré Editores Ltda. 6ta Edición. Bogotá D.C., 2014.Pág. 337. 
que en el segundo contrato se debe tener en cuenta la nulidad que prevé el art. 1092 para el caso en que haya mala fe del asegurado en su contratación y, en todo caso,al ocultar maliciosamente la coexistencia de seguros en el aviso del siniestro, en ambos seguros debe operar la pérdida del derecho a la indemnización prevista en el artículo 1076 del C.Co.

Nuestro ordenamiento regula la forma en que los aseguradores se distribuirán la indemnización del siniestro cuando se declara la coexistencia de seguros con atención a los límites indemnizables y en proporción a sus respectivos contratos al haber buena fe por parte del asegurado:

Art. 1092. C.Co. "En el caso de pluralidad o de coexistencia de seguros, los aseguradores deberán soportar la indemnización debida al asegurado en proporción a la cuantía de sus respectivos contratos, siempre que el asegurado haya actuado de buena fe. La mala fe en la contratación de éstos produce nulidad."

Al no ser la coexistencia misma el objeto de prohibición, la Ley simplemente establece cómo se desarrolla el principio indemnizatorio en este caso, reiterándolo para la figura del Coaseguro, figura jurídica que se da en virtud de la concurrencia de voluntades entre los mismos aseguradores, por petición o con conocimiento del asegurado. $^{45}$

También contempla el Código de Comercio la pérdida del derecho a la indemnización como consecuencia del no aviso de coexistencia de seguros que obedece a la mala fe del asegurado:

Art. 1076 C.Co. "Sin perjuicio de la obligación que le impone el artículo 1074, el asegurado estará obligado a declarar al asegurador, al dar la noticia del siniestro, los seguros coexistentes, con indicación del asegurador y de la suma asegurada. La inobservancia maliciosa de esta obligación le acarreará la pérdida del derecho a la prestación asegurada."

Lo anterior, en concordancia con el art. 1078 del Código de Comercio, norma que reglamente de forma genérica las consecuencias de los deberes del asegurado con posterioridad a la ocurrencia del siniestro, ${ }^{46}$ donde se establece que "la mala fe

45 Art. 1095 C.Co. "Las normas que anteceden (relativas a coexistencia de seguros) se aplicarán igualmente al coaseguro, en virtud del cual dos o más aseguradores, a petición del asegurado o con su aquiescencia previa, acuerdan distribuirse entre ellos determinado seguro

46 "La desatención de las obligaciones que deriva en la disminución de la indemnización a que alude el artículo 1078 del Código de Comercio, está concebido para aquellos casos en que el asegurado no evita la extensión y propagación del daño, cuando deja de proveer el salvamento de las cosas aseguradas, si demora el aviso del siniestro o no declara al dar noticia del siniestro los seguros coexistentes, en los términos de los artículos 1074 al 1076 ibídem, sin perjuicio en este último caso de lo previsto por el artículo 1093 id." Corte 
del asegurado o del beneficiario en la reclamación o comprobación del derecho al pago de determinado siniestro causará la pérdida de tal derecho".

\section{Naturaleza y consecuencia jurídica de la cláusula que prohíbe al asegurado reconocer su responsabilidad y efectuar acuerdos con el tercero}

Hemos visto que las distintas consecuencias jurídicas que puede surtir el incumplimiento de los deberes a cargo del asegurado obedecen a la relación que ellas tienen con el riesgo, con base en el estado en que este se encuentre en el contrato de seguro. Así, es importante iniciar este acápite reiterando que la existencia de distintos regímenes jurídicos para los deberes del asegurado no se da por capricho del legislador, sino que entraña una verdadera sistematización de las cláusulas contentivas de los deberes del asegurado en el contrato de seguro en las distintas etapas contractuales en razón del estado del riesgo.

El seguro de responsabilidad civil pertenece a los seguros patrimoniales, puesto que el interés asegurable es la posible afectación patrimonial del asegurado al generar perjuicios a otros mediante hechos en los que se comprometa su responsabilidad civil. ${ }^{47}$ De ahí surge una particularidad en el contrato de seguro de responsabilidad civil, puesto que el beneficiario es entonces una persona distinta del asegurado. ${ }^{48}$

Entre el asegurado y el tercero víctima -Eventual beneficiario- existe una relación de responsabilidad civil, en la que el asegurador es un tercero cuyo patrimonio se puede comprometer en virtud del contrato de seguro. Esta situación puede dar lugar a que el asegurado afronte la ocurrencia del riesgo de forma negligente, lo cual es una actitud contraria al deber de cuidado del riesgo que se refleja como finalidad de los deberes del asegurado con posterioridad a la ocurrencia del siniestro. ${ }^{49}$

Suprema de Justicia, Sala de Casación Civil y Agraria. Sentencia del 18 de diciembre de 2013. M.P. Fernando Giraldo Gutiérrez. Expediente 359.

47 "Dado que el seguro de responsabilidad tiene por objeto, además de proteger a la víctima, salvaguardar el patrimonio del potencial responsable (quien es el asegurado), el interés se circunscribe a la preservación de dicho patrimonio que es susceptible de erosionarse por deudas de responsabilidad" Ver DIAZ-GRANADOS, Juan Manuel. El Seguro de Responsabilidad. Pág. 99.

48 "el seguro de responsabilidad no otorga protecciones sobre cosas determinadas, dado que cubre la integridad patrimonial del responsable, función que se complementa a partir de la Ley 45 de 1990 mediante el resarcimiento de la víctima, que, en principio, se constituye en el beneficiario de la indemnización." Ibídem. Pág. 9.

49 "En caso de siniestro las consecuencias económicas impactarán primordialmente al asegurador más que al asegurado. Este último, a lo sumo, estará llamado a asumir el deducible o franquicia que se hubiese pactado en la póliza y, eventualmente, perjuicios que excedan la suma asegurada o excluidos de la cobertura. De lo anterior se evidencia que al asegurador le asiste un especial interés en el proceso que la víctima inicie en contra del asegurado y, por supuesto, en la conducta que este despliegue, por lo cual es usual que en el seguro de 
Al ser el asegurador el tercero cuyo patrimonio también puede verse afectado por las conductas que asuman el asegurado y el beneficiario, es natural que pretenda precaver los perjuicios que puedan representarse por una posible colusión entre el asegurado y el tercero/beneficiario, lo cual explica la inclusión de esta cláusula en el contrato de seguro a fin de garantizar que la obligación del asegurador no supere la real magnitud que el siniestro tendría si el asegurado hubiese actuado diligentemente ante la ocurrencia del siniestro. Esta circunstancia ha de presentar total simetría con la consecuencia jurídica que le sea natural a la prohibición de incurrir en ella.

\subsection{Efectos del Reconocimiento de Responsabilidad del Asegurado y del Acuerdo con el Tercero.}

Una vez ha ocurrido un hecho que pueda ser susceptible de considerarse como siniestro en el contrato de seguro de responsabilidad civil por configurar la realización del riesgo asegurado, es posible que el asegurado reconozca al tercero su culpabilidad por la ocurrencia del hecho, situación que observaremos que no está llamada constituir acreditación de la realización del riesgo asegurado ni de la cuantía de los daños ocasionados. También es posible que el asegurado realice un acuerdo conciliatorio o transaccional con el tercero, circunstancia que consideramos tampoco está llamada a generar efectos negativos para el asegurador.De acuerdo con el artículo 1077 del Código de Comercio, el asegurado y/o el beneficiario han de acreditar ante el asegurador la ocurrencia del siniestro y la cuantía de los daños de él derivados, por lo que el alcance del reconocimiento de responsabilidad del asegurado no puede entenderse como confesión al no verse el asegurado perjudicado con dicho reconocimiento en razón de la existencia del contrato de seguro que ampara su responsabilidad. ${ }^{50} \mathrm{~A}$ la luz de este contrato, el reconocimiento de responsabilidad del asegurado le permite obtener el pago de los daños por él ocasionados, circunstancia que le resulta beneficiosa.

responsabilidad existan cargas y deberes que otorgan al asegurador la dirección del proceso y restringen la conducta del asegurado" Ver DÍAZ-GRANADOS, Juan Manuel. EL SEGURO DE RESPONSABILIDAD. Pontificia Universidad Javeriana y Universidad del Rosario. 2da Edición. Bogotá, Colombia. Pág. 205.

50 La confesión como medio probatorio requiere que verse sobre hechos que produzcan consecuencias jurídicas adversas al confesante, circunstancia que no se configura en este caso pues al pretender el pago de indemnización, el reconocimiento de responsabilidad estaría encaminado a producir consecuencias que favorezcan al asegurado o el tercero, adversas al asegurador. Al respecto ha manifestado la Corte Suprema de Justicia:

“(...) el asegurado no es quien puede fijar o admitir responsabilidad, no sólo porque eso desnaturalizaría el carácter aleatorio del seguro, sino porque en el campo probatorio, se trataría de un hecho que lo beneficiaría(...)" Ver Corte Suprema de Justicia, Sala de Casación Civil y Agraria. Sentencia del 9 de agosto de 2010. M.P. Jaime Alberto Arrubla Paucar. Expediente 524. Reiterada en, Corte Suprema de Justicia, Sala de Casación Civil y Agraria. Sentencia del 5 de julio de 2012. M.P. Fernando Giraldo Gutiérrez. Expediente 425. 
Por lo anterior, al sustentar el asegurado o el beneficiario la solicitud indemnizatoria con base en dicho reconocimiento no se cumpliría con la carga probatoria a su cargo..$^{51}$ $\mathrm{Al}$ igual que como ocurre con los pagos que pueda efectuar el asegurado al tercero. ${ }^{52}$

Por lo anterior, también es oportuna la precisión que realiza la Corte respecto del alcance probatorio del acuerdo con el tercero o reconocimiento de responsabilidad del asegurado:

"si conforme al anexo de indemnización profesional, acápite "condiciones", numeral $6^{\circ}$, el 'Asegurado no deberá reconocer responsabilidad (...) sin el previo consentimiento de la Aseguradora", surge claro que los "actos evidentemente negligentes' no podían dejarse por acreditados con la decisión de la Junta Directiva de [El Asegurado], sobre que "su responsabilidad profesional", respecto de terceros, en la generación de las pérdidas, estaba "seriamente comprometida"53

En esta sentencia, después de un profundo análisis probatorio en este mismo sentido para el caso en particular, la Corte Suprema desarrolla la insuficiencia probatoria del reconocimiento de responsabilidad del asegurado al carecer de la entidad jurídica idónea para cumplir con la carga que el artículo 1077 del Código de Comercio le impone al asegurado, dándole especial énfasis a un Acta de la Junta Directiva del Asegurado, en la que declaraba que sus actos habían sido "evidentemente negligentes" y reconocía que comprometían su responsabilidad profesional.

Ahora bien, la celebración de un contrato de transacción o conciliación que el asegurado celebre con el beneficiario, no le es oponible al asegurador, pues éste es un tercero frente a dicho contrato, por lo que no está llamado a generar efectos jurídicos para él sin su consentimiento ${ }^{54}$ a menos que le sea favorable,

51 "las comprobaciones que corren por cuenta del asegurado o el beneficiario, según corresponda, para dar inicio al cómputo del término señalado, pueden verificarse, aún extrajudicialmente, pues así lo autoriza el artículo 1080 del mismo cuerpo normativo, acudiendo para tal efecto a medios adecuados de convicción, es decir, con fuerza suficiente para demostrar, como ya se dijo, tanto la ocurrencia del riesgo asegurado, como el monto del daño que por su causa ha reportado." Corte Suprema de Justicia, Sala de Casación Civil y Agraria. Sentencia del 29 de noviembre de 2009. M.P. Jaime Alberto Arrubla Paucar. Expediente 9730-0351.

52 El hecho de que el asegurado, con ocasión de la ocurrencia del siniestro efectúe pagos en favor del tercero no implica per se que el siniestro haya comprometido la responsabilidad civil del asegurado, así como tampoco que el pago obedezca a una indemnización. Por ello, tendrá que acreditarse ante el asegurador la ocurrencia y cuantía del siniestro en los términos del artículo 1077 del Código de Comercio.

53 Corte Suprema de Justicia, Sala de Casación Civil y Agraria. Sentencia del 9 de agosto de 2010. M.P. Jaime Alberto Arrubla Paucar. Expediente 524.

54 "El principio general, como se ha visto, es el de la relatividad de los efectos de la convención. Tales efectos no se extienden a los terceros; no pueden obrar ni en su provecho ni en su perjuicio, puesto que ellos no participaron en la formación del contrato." TAMAYO LOMBANA, Alberto. MANUAL DE OBLIGACIONES. Ed. Derecho y ley. Bogotá. Pág. 260. 
caso en el cual el asegurador no habría de tener objeción alguna a la realización de dicho acuerdo. ${ }^{55}$

El acuerdo al que arriban el asegurado y el beneficiario constituye una disposición que hace éste del derecho al resarcimiento patrimonial por los daños que le fueron ocasionados por aquél. En el evento en que la cuantía del acuerdo sea inferior a la cuantía que se acredite como valor de la pérdida, el tercero/beneficiario no podrá pretender en contra del asegurador la diferencia entre estos valores, pues él ya dispuso de su derecho teniéndolo por satisfecho en virtud del contrato de transacción o acuerdo conciliatorio. Dicha situación le resulta provechosa al asegurador, puesto que su obligación de indemnizar al tercero se encuentra limitada por el monto de la obligación indemnizatoria a cargo del asegurado, la cual es objeto del acuerdo entre este y el beneficiario. ${ }^{56}$

Lo anterior se da independientemente de que el asegurado y el beneficiario hayan deseado generar dicho efecto a favor del asegurador, o incluso haber reparado en él.57

Tampoco constituye el contrato de transacción o conciliación acreditación alguna de la ocurrencia del siniestro ni de la cuantía de los daños, pues recae sobre derechos disponibles de las partes y carece de la entidad probatoria suficiente para cumplir con la carga contemplada en el artículo 1077 del Código de Comercio. A la luz del principio de la autonomía de la voluntad privada, es claro que dos personas pueden realizar un acuerdo, pago, declaración, etc., sin que exista un deber jurídico de realizarlo, sino por el simple ejercicio de la autonomía de su voluntad.

Ahora bien, encontramos que la Jurisprudencia de la Corte Suprema de Justicia se ha aproximado al tema analizándolo a partir del artículo 1054 del Código de Comercio, la inasegurabilidad de los hechos meramente potestativos del asegurado o el benefi-

55 El artículo 1506 del Código Civil permite que se estipule en favor de un tercero, lo que se ve reflejado en el caso que nos ocupa cuando el acuerdo al que arriban las partes en el contrato de transacción o conciliación represente un quantum inferior al indemnizable a los ojos del contrato de seguro, lo que permite que el asegurador se acoja al quantum pactado entre el asegurado y el beneficiario a la hora de determinar el monto a indemnizar en virtud del contrato de seguro.

56 "Mediante la consagración del postulado de la autonomía de la voluntad privada, el legislador delega en los particulares la potestad de arreglar mediante actos jurídicos gran parte de sus relaciones, sobre todo las de contenido patrimonial o económico. Es así como ellos pueden crear convencionalmente esas relaciones y, del mismo modo, modificarlas o extinguirlas." OSPINA FERNÁNDEZ, Guillermo. RÉGIMEN GENERAL DE LAS OBLIGACIONES. Ed. Temis. 8 ${ }^{\text {va }}$ Edición. Bogotá D.C., 1980. Pág. 314.

57 En este evento, el monto de la obligación de responsabilidad civil a cargo del asegurado corresponde al valor indemnizable como límite de la indemnización, por corresponder al monto efectivo del perjuicio patrimonial sufrido por el asegurado o el beneficiario, en concordancia con el artículo 1089. Del Código de Comercio. 
ciario. ${ }^{58} \mathrm{Al}$ corresponder tanto el reconocimiento de responsabilidad como el acuerdo con el tercero a hechos que obedecen a la potestad del asegurado y el beneficiario, no pueden considerarse riesgos asegurables, así como tampoco pueden considerarse prueba de la ocurrencia del siniestro ni de la cuantía de la pérdida.

Debemos recordar que no es el reconocimiento de responsabilidad del asegurado o el acuerdo entre éste y el tercero el riesgo cuya realización constituye siniestro, ${ }^{59}$ sino que tanto uno como otro caso se dan con posterioridad a la realización del siniestro, indistintamente de que su cobertura sea por ocurrencia o por descubrimiento, pues tanto el reconocimiento como el acuerdo versan sobre dicho suceso.

Observamos entonces que el reconocimiento de responsabilidad no constituye acreditación de ocurrencia del siniestro ni de su cuantía, así como el acuerdo que el asegurado y el tercero realicen tampoco puede generar dichos efectos por serle inoponible al asegurador cuando se dé por un monto inferior al valor indemnizable.

Son distintos el incumplimiento de esta prohibición de la acreditación del siniestro y de la cuantía de la pérdida, por lo que pueden generarse distintas situaciones en las que no siempre se va a causar un perjuicio al asegurador, quien además debe ceñirse al principio indemnizatorio al efectuar el pago de su obligación condicional. Más importante aún, no debe entenderse el incumplimiento de esta prohibición como incurrencia del asegurado o el beneficiario en mala fe.

\subsection{Improcedencia de Liberación del Asegurador de Efectuar el Pago de Indemnización como Consecuencia Jurídica del Incumplimiento de la Cláusula Prohibitiva.}

La prohibición al asegurado de reconocer su responsabilidad y efectuar acuerdos con el tercero, al comportar la prevención del asegurador de verse perjudicado a raíz de

58 "(...) acaecido el hecho externo imputable al asegurado, el éxito de las acciones contra el asegurador, sea que las promueva aquél por las "prestaciones que se le reconozcan" (artículo 1127), ya directamente por el tercero perjudicado (artículo 1133), exige zanjar judicialmente la responsabilidad, pues eso es lo que, precisamente determina el siniestro. Desde luego que como el riesgo, esto es, en general, el suceso futuro incierto, cuya realización da lugar a la obligación del asegurador, no puede depender "exclusivamente de la voluntad del tomador, del asegurado o del beneficiario" (artículo 1054 del Código de Comercio), es claro que cuando no media el conocimiento y aceptación de la sociedad aseguradora, el asegurado no es quien puede fijar o admitir responsabilidad, no sólo porque eso desnaturalizaría el carácter aleatorio del seguro, sino porque en el campo probatorio, se trataría de un hecho que lo beneficiaría(...)" Ver Corte Suprema de Justicia, Sala de Casación Civil y Agraria. Sentencia del 9 de agosto de 2010. M.P. Jaime Alberto Arrubla Paucar. Expediente 524. Reiterada en, Corte Suprema de Justicia, Sala de Casación Civil y Agraria. Sentencia del 5 de julio de 2012. M.P. Fernando Giraldo Gutiérrez. Expediente 425.

59 Ver Corte Suprema de Justicia, Sala de Casación Civil y Agraria. Sentencia del 9 de agosto de 2010. M.P. Jaime Alberto Arrubla Paucar. Expediente 524. 
la conducta del asegurado después de ocurrido el siniestro, debe generar una consecuencia acorde con su objeto y finalidad.

Es posible que el acuerdo entre el asegurado y el tercero corresponda a una cuantía inferior o igual a la de los daños que sufra el tercero, así como también puede el asegurado reconocer su responsabilidad respecto de un hecho en el que ciertamente se encuentre comprometida, por lo que no necesariamente el incumplimiento de esta obligación contraríe el principio indemnizatorio que rige la obligación condicional del asegurador.

Así mismo, tampoco puede presumirse que el incumplimiento de esta obligación implique la mala fe del asegurado, puesto que se vulneraría la presunción constitucional de buena $\mathrm{fe}^{60} \mathrm{y}$, desde el ámbito del contrato de seguro, la mala fe del asegurado en esta etapa contractual se sanciona con la pérdida del derecho a la indemnización. ${ }^{61}$

No es razonable la liberación del asegurador de cumplir con su obligación condicional cuando el asegurado reconoce tener responsabilidad respecto de un hecho en el que esta se vio realmente comprometida o cuando el asegurado celebra un acuerdo con el tercero por una cuantía inferior o igual a la de los daños sufridos por

60 "La Corte ha señalado que la buena fe es un principio que de conformidad con el artículo 83 de la Carta Política se presume y conforme con este (i) las actuaciones de los particulares y de las autoridades públicas deben estar gobernadas por el principio de buena fe y; (ii) ella se presume en las actuaciones que los particulares adelanten ante las autoridades públicas, es decir en las relaciones jurídico administrativas, pero dicha presunción solamente se desvirtúa con los mecanismos consagrados por el ordenamiento jurídico vigente, luego es simplemente legal y por tanto admite prueba en contrario." Corte Constitucional, Sentencia C-1194 de 2008. M.P. Jaime Araujo Rentería.

61 "Es una sanción de tal trascendencia, tan opuesta a la esencia protectora del seguro, que el nuevo Código de Comercio la reserva a infracciones maliciosas del asegurado, enderezadas a defraudar al asegurador o a causar detrimento a los derechos que le confiere la ley, como serían las de los deberes de "no renunciar... a sus derechos contra terceros responsables del siniestro" (artículo 1097), "declarar al asegurador, al dar noticia del siniestro, los seguros coexistentes con indicación del asegurador y de la suma asegurada" (artículo 1076), "o el de proceder con lealtad y buena fe en la promoción y prueba de su reclamación" (artículo 1078). Hay, además, otras contravenciones que escapan a la caducidad y se sancionan tan sólo con la indemnización de los perjuicios que se hayan irrogado al asegurador (artículo 1078)." "Tratándose de una sanción que es, además, la más drástica a que puede dar origen la infracción del contrato, o sea la pérdida del derecho a la indemnización debe ella aplicarse con criterio restrictivo. Favores sint ampliandi et odia restringenda. Y sin perder de vista, además de su fundamento ético, jurídico y técnico, la magnitud del daño causado con la infracción. Ya se ha dicho que su fundamento ético-jurídico radica en la necesidad que tiene el asegurador de prevenir el fraude. Puede agregarse que su soporte técnico es el equilibrio financiero de los riesgo vinculados a la comunidad." Ver Laudo Arbitral. Banco de Bogotá vs Seguros Comerciales Bolívar, Aseguradora Colseguros y Seguros Tequendama. Árbitros Hernando Morales Molina, J. Efrén Ossa Gómez, Daniel Rivera Villate. 17 de septiembre de 1974. 
el siniestro que compromete su responsabilidad, pues dichos supuestos fácticos no afectan el principio indemnizatorio ni generan perjuicio al asegurador.

Cabe recordar que es posible que el acuerdo con el tercero pueda implicar una disminución del valor a indemnizar por parte del asegurador. El lucro cesante del tercero es objeto de cobertura del seguro de responsabilidad civil, por cuanto para el asegurado representa un daño emergente. Por ello, al celebrarse un acuerdo entre el asegurado y el tercero, este acepta tener por satisfecho su derecho a la indemnización por la cuantía que en ese acuerdo se defina, evitando además la extensión o propagación del siniestro en el tiempo, lo cual constituye para el asegurado una obligación en el contrato de seguro, como ya hemos señalado.

Por lo anterior, el considerar que el incumplimiento de esta obligación da lugar a la liberación del asegurador con independencia de los distintos efectos que realmente pueda generar frente al contrato de seguro, rompe con el esquema de proporcionalidad que caracteriza el contrato de seguro.

\subsection{Aplicación del Artículo 1078 del Código de Comercio a la Cláusula que Prohíbe al Asegurado Reconocer su Responsabilidad y Realizar Acuerdos con el Tercero.}

Como obligación del asegurado con posterioridad a la ocurrencia del siniestro, esta obligación comparte la naturaleza jurídica, justificación y finalidad que las demás cláusulas que contienen obligaciones para el asegurado al momento de realizarse el riesgo, puesto que pretende que el asegurado afronte la ocurrencia del siniestro como si los perjuicios patrimoniales aún se encontraran en su cabeza, buscando que el valor que sea reclamado con posterioridad a la compañía corresponda realmente al valor de los perjuicios derivados de la ocurrencia del siniestro.

El reconocimiento de responsabilidad o acuerdo con el tercero por parte del asegurado, si bien constituye un incumplimiento de la obligación de no hacer contenida en la cláusula prohibitoria, no siempre es un acto de mala fe del asegurado, así como tampoco se puede considerar que esté llamado a generar siempre un perjuicio para el asegurador, pues bien podría beneficiarle, como ya hemos mencionado.

El incumplimiento de esta obligación del asegurado puede generar distintos tipos de efectos al confrontarse con el principio indemnizatorio del contrato de seguro y el principio de buena fe, por lo que no le es natural tener una consecuencia jurídica estática como la liberación del asegurador de satisfacer la obligación condicional a su cargo, menos cuando esta también constituye una sanción a la mala fe.

El artículo 1078 del Código de Comercio establece una consecuencia jurídica para las obligaciones del asegurado con posterioridad a la ocurrencia del siniestro, en los siguientes términos: 
"Si el asegurado o el beneficiario incumplieren las obligaciones que les corresponden en caso de siniestro, el asegurador sólo podrá deducir de la indemnización el valor de los perjuicios que le cause dicho incumplimiento.

La mala fe del asegurado o del beneficiario en la reclamación o comprobación del derecho al pago de determinado siniestro, causará la pérdida de tal derecho."

La pérdida del derecho a la indemnización ocurre como sanción a la mala fe del asegurado o beneficiario al reclamar al asegurador el pago de la indemnización, por lo que todo acuerdo que ellos efectúen o reconocimiento de responsabilidad por parte del asegurado incurriendo en mala fe debe ser sancionado de igual manera, no por el incumplimiento de la prohibición que hoy nos ocupa, sino por haberse dado el reconocimiento o el acuerdo con la finalidad maliciosa de efectuar la reclamación con base en él. ${ }^{62}$

De otra parte, cuando el incumplimiento de esta obligación se da sin vulnerarse la buena fe del asegurado, es natural que su consecuencia jurídica sea la contemplada en el inciso primero de la norma citada, pues no existe motivo alguno por el cual el asegurador deba dejar de cumplir con la obligación condicional exigible desde la realización del riesgo asegurado.

Independientemente del acuerdo o reconocimiento de responsabilidad, el asegurado y el beneficiario no se liberan de su carga de acreditar al asegurador la ocurrencia del siniestro ni la cuantía de la pérdida, pues es con base en el cumplimiento de esta carga probatoria que el asegurador ha de efectuar el pago de indemnización. Por lo anterior, teniendo en cuenta que ni el reconocimiento de responsabilidad del asegurado ni el acuerdo entre este y el tercero tienen la entidad suficiente para acreditar por sí mismos la ocurrencia ni la cuantía del siniestro, el asegurador ha de indemnizar según le sea acreditado de acuerdo con el artículo 1077 del Código de Comercio. ${ }^{63}$

62 "Naturalmente, no solo el seguro sino todo negocio jurídico parte de la buena fe, de la ausencia de intención dolosa, de ánimo de defraudar. Empero, dentro del campo que abarca el seguro el concepto adquiere connotación más estricta porque, a diferencia de muchos contratos en que la habilidad u suspicacia de las partes pueden llevarlas a obtener ciertas ventajas amparadas por la ley, en el contrato de seguro, donde es necesario tomar como base la buena fe, la ubérrima bona fides de que innecesariamente se habla pues el concepto no admite grados, son drásticamente sancionadas conductas acaso irrelevantes en otros negocios jurídicos." Ver. LÓPEZ BLANCO, Hernán Fabio. CARACTERÍSTICAS DEL CONTRATO DE SEGURO. Pág. 139.

63 "(...) acaecido el hecho externo imputable al asegurado, el éxito de las acciones contra el asegurador, sea que las promueva aquél por las "prestaciones que se le reconozcan" (artículo 1127), ya directamente por el tercero perjudicado (artículo 1133), exige zanjar judicialmente la responsabilidad, pues eso es lo que, precisamente determina el siniestro. Desde luego que como el riesgo, esto es, en general, el suceso futuro incierto, cuya realización da lugar a la obligación del asegurador, no puede depender "exclusivamente de la voluntad del tomador, del asegurado o del beneficiario" (artículo 1054 del Código de Comercio), es claro que cuando no media el conocimiento y aceptación de la sociedad aseguradora, el asegurado no es 
Por lo anterior, en caso de que el acuerdo genere un perjuicio para el asegurador, este podrá descontarlo del valor a indemnizar, y en caso de que el asegurado utilice el acuerdo de mala fe en la reclamación al asegurador, ha de perder su derecho al pago de indemnización. Lo anterior, enfatizando a que la pérdida del derecho a la indemnización es consecuencia de la mala fe en la realización del acuerdo o reconocimiento de responsabilidad, puesto que de lo contrario la consecuencia no sería congruente con la naturaleza de la prohibición y los distintos efectos que su incumplimiento pueda generar.

De esta forma, podemos observar como la consecuencia jurídica que el artículo 1078 del Código de Comercio contempla para las obligaciones a cargo del asegurado que se encuentran relacionadas con el riesgo realizado le es aplicable también a la obligación contenida en la cláusula que prohíbe al asegurado reconocer su responsabilidad y realizar acuerdos con el asegurado, pues esta obligación de no hacer pertenece a la especie de obligaciones referidas al riesgo realizado y la aplicación de dicha consecuencia jurídica a esta obligación se encuentra en armonía con el desarrollo jurídico que se refleja en la regulación normativa en torno a los deberes del asegurado en razón de su relación con el riesgo y el desarrollo de los principios rectores del derecho de seguros.

\section{CONCLUSIONES}

Si bien existe una considerable variedad en las consecuencias jurídicas que se pueden derivar del incumplimiento de los distintos deberes del asegurado, hemos visto que no es errática la asignación de consecuencia jurídica que da nuestro legislador a cada especie de deberes del asegurado, sino que entraña una categorización que parte del riesgo asegurado como criterio de distinción.

El riesgo tiene la virtualidad de poder realizarse o no durante la vigencia del seguro, de manera que pueden cambiar las conductas que en torno a él deben asumir las partes e intervinientes en el contrato de seguro. Por ello, el régimen jurídico de los deberes que contractualmente surgen para el asegurado está llamado a variar en función de la etapa contractual de que se trate: i) antes o al momento de transferirse el riesgo al asegurador, ii) mientras el riesgo esté a cargo del asegurador, y iii) habiéndose realizado el riesgo estando a cargo del asegurador.

En desarrollo de esta investigación hemos observado que las distintas consecuencias en el incumplimiento de los deberes del asegurado buscan determinados objetivos y desarrollan principios que rigen el contrato de seguro, por lo que al momento de

quien puede fijar o admitir responsabilidad, no sólo porque eso desnaturalizaría el carácter aleatorio del seguro, sino porque en el campo probatorio, se trataría de un hecho que lo beneficiaría(...)" Ver Corte Suprema de Justicia, Sala de Casación Civil y Agraria. Sentencia del 9 de agosto de 2010. M.P. Jaime Alberto Arrubla Paucar. Expediente 524. Reiterada en, Corte Suprema de Justicia, Sala de Casación Civil y Agraria. Sentencia del 5 de julio de 2012. M.P. Fernando Giraldo Gutiérrez. Expediente 425. 
determinar cuál ha de ser la consecuencia jurídica para el incumplimiento de algún deber en particular del asegurado, debemos acudir a este criterio distintivo.

De esta forma hemos abordado el estudio de la prohibición que en el seguro de responsabilidad civil se establece para el asegurado, consistente en no reconocer su responsabilidad ni realizar acuerdos con el tercero/beneficiario. Esta prohibición debe ser cumplida por el asegurado después de que el riesgo se haya realizado, pues ese reconocimiento o acuerdo se refiere al riesgo realizado o siniestro, por lo que de acuerdo con la categorización planteada en este estudio, su consecuencia jurídica adecuada debe encontrarse acorde con las de los demás deberes de su especie.

Al analizar los deberes que debe cumplir el asegurado al realizarse el riesgo encontramos que ellos reflejan el principio indemnizatorio del contrato de seguro, pues persiguen finalidades encaminadas a que el asegurado permita al asegurador conocer oportunamente la ocurrencia del siniestro, ejercer efectivamente los derechos que surgen pagar la indemnización, poder tomar medidas para evitar la extensión o propagación del siniestro e, incluso, exigir esta última conducta al mismo asegurado.

En el fondo, todas estas finalidades de esta categoría de deberes a cargo del asegurado entrañan al principio indemnizatorio imperante en el contrato de seguro, el pago de un valor que satisfaga plenamente las pérdidas derivadas del siniestro, sin que se genere enriquecimiento para el asegurado/beneficiario.

Así mismo, encontramos que también comparten estos deberes un régimen jurídico en virtud del cual la consecuencia jurídica de su incumplimiento consiste en que el asegurador puede deducir de la indemnización el valor de los perjuicios que le cause dicho incumplimiento. Paralelamente, encontramos que cuando el asegurado obra de mala fe en la reclamación o comprobación del derecho al pago del siniestro, hay lugar a una consecuencia jurídica más gravosa, incluso sancionatoria, en razón de la especial buena fe característica del contrato de seguro: la pérdida del derecho a recibir el pago de la indemnización.

No obstante lo anterior, en el mercado colombiano se le ha dado una consecuencia distinta a la prohibición al asegurado de reconocer su responsabilidad o realizar acuerdos con el tercero, pues se ha contemplado la consecuencia sancionatoria propia de la mala fe, independientemente de que el asegurado incumpla la prohibición con mala o buena fe. Esta consecuencia es, a todas luces, desproporcionada e inconsecuente con los efectos de este incumplimiento en la ejecución del contrato de seguro.

Esta prohibición comparte con los demás deberes del asegurado con posterioridad al siniestro el propósito de preservar el carácter indemnizatorio de la indemnización a pagar por parte del asegurador en la medida en que puntualmente busca que el asegurado no comprometa la responsabilidad del asegurador más allá de lo que la realización del riesgo realmente lo hace. 
Hemos observado que tanto el reconocimiento de responsabilidad como el acuerdo con el tercero no siempre buscan vulnerar el principio indemnizatorio, puesto que carecen de la entidad necesaria para acreditar la ocurrencia del siniestro ni la cuantía del mismo y existen eventos en los que incluso el incumplimiento de este incumplimiento beneficia al asegurador.

Dado que los efectos del reconocimiento de responsabilidad y del acuerdo entre el asegurado y el tercero varían respecto del principio indemnizatorio, le es natural que su consecuencia jurídica pueda modularse en proporción a la medida en que este incumplimiento pueda irrumpir con el carácter indemnizatorio del pago del asegurador, perjudicándole.

Es así como llegamos a la conclusión de que, en efecto, la reducción del monto de la indemnización en proporción a los perjuicios ocasionados al asegurador es la consecuencia jurídica adecuada para el incumplimiento de la prohibición al asegurado de reconocer su responsabilidad y realizar acuerdos con el tercero, pues se ajusta a la naturaleza jurídica de dicha prohibición al comprenderse en la categoría de deberes del asegurado con posterioridad a la ocurrencia del siniestro, con la particularidad de pertenecerle particularmente al seguro de responsabilidad civil.

\section{BIBLIOGRAFÍA}

CLARKE, Malcolm A. THE LAW OF INSURANCE CONTRACTS. Second Edition. Lloyd's of London Press Ltd. 1994.

Corte Constitucional, Sentencia C-1194 de 2008. M.P. Jaime Araujo Rentería.

Corte Suprema de Justicia, Sala de Casación Civil y Agraria. Sentencia del 13 de octubre de 1995. M.P. Hector Marín Naranjo. Expediente 3986

Corte Suprema de Justicia, Sala de Casación Civil y Agraria. Sentencia del 29 de enero de 1998. M.P. Carlos Esteban Jaramillo Schloss. Expediente 4894.

Corte Suprema de Justicia, Sala de Casación Civil y Agraria. Sentencia del 22 de julio de 1999. M.P. Nicolas Bechara Simancas. Expediente 5065.

Corte Suprema de Justicia, Sala de Casación Civil y Agraria. Sentencia del 14 de diciembre de 2001 M.P. Jorge Antonio Castillo Rugeles. Expediente 5952.

Corte Suprema de Justicia, Sala de Casación Civil y Agraria. Sentencia del 30 de septiembre de 2002. M.P. Carlos Ignacio Jaramillo Jaramillo. Expediente No. 4799.

Corte Suprema de Justicia, sala de Casación Civil y agraria. Sentencia del 16 de diciembre de 2005. M.P. Jaime Alberto Arrubla Paucar. Exp. No. 206.

Corte Suprema de Justicia, Sala de Casación Civil y Agraria. Sentencia del 19 de diciembre de 2006. M.P. Pedro Octavio Munar Cadena. Expediente 311.

Corte Suprema de Justicia, Sala de Casación Civil y Agraria. Sentencia del 28 de febrero de 2007. M.P. Carlos Ignacio Jaramillo Jaramillo. Expediente 133.

Corte Suprema de Justicia, Sala de Casación Civil y Agraria. Sentencia del 6 de julio de 2007. M.P. Carlos Ignacio Jaramillo Jaramillo. Expediente 359. 
Corte Suprema de Justicia, Sala de Casación Civil y Agraria. Sentencia del 6 de mayo de 2009. M.P. William Namén Vargas. Expediente 083.

Corte Suprema de Justicia, Sala de Casación Civil y Agraria. Sentencia del 29 de noviembre de 2009. M.P. Jaime Alberto Arrubla Paucar. Expediente 9730-0351.

Corte Suprema de Justicia, Sala de Casación Civil y Agraria. Sentencia del 9 de agosto de 2010. M.P. Jaime Alberto Arrubla Paucar. Expediente 524.

Corte Suprema de Justicia, Sala de Casación Civil y Agraria. Sentencia del 23 de noviembre de 2010. M.P. Edgardo Villamil Portilla. Expediente 198.

Corte Suprema de Justicia, Sala de Casación Civil y Agraria. Sentencia del 5 de julio de 2012. M.P. Fernando Giraldo Gutiérrez. Expediente 425.

Corte Suprema de Justicia, Sala de Casación Civil y Agraria. Sentencia del 9 de julio de 2012. M.P. Ariel Salazar Ramírez. Expediente 101.

Corte Suprema de Justicia, Sala de Casación Civil y Agraria. Sentencia del 18 de diciembre de 2013. M.P. Fernando Giraldo Gutiérrez. Expediente 359.

DÍAZ-GRANADOS, Juan Manuel. El Seguro de Responsabilidad. Pontificia Universidad Javeriana y Universidad del Rosario. 2da Edición. Bogotá, Colombia.

JARAMILLO JARAMILLO, Carlos Ignacio. DERECHO DE SEGUROS. Estudios y Escritos Jurídicos. Tomo II El Contrato de Seguro, Teoría General del Contrato. Editorial Temis. 2011. Bogotá D.C.

Laudo Arbitral. Fundación Santa Fe de Bogotá vs. Compañía Mundial de Seguros. Árbitro. Fernando Hinestrosa.

Laudo Arbitral. Banco de Bogotá vs Seguros Comerciales Bolívar, Aseguradora Colseguros y Seguros Tequendama. Árbitros Hernando Morales Molina, J. Efrén Ossa Gómez, Daniel Rivera Villate. 17 de septiembre de 1974.

Laudo Arbitral Comercializadora Internacional Pesquera Vikingos de Colombia S.A. vs Aseguradora Colseguros S.A. Árbitro. Bernardo Botero Morales. 16 de octubre de 2002.

LÓPEZ BLANCO, Hernán Fabio. COMENTARIOS AL CONTRATO DE SEGURO. Dupré Editores Ltda. 6ta Edición. Bogotá D.C., 2014.

LÓPEZ SAAVEDRA, Domingo M., y FACAL Carlos J.M., "Tratado de Derecho Comercial Seguros". Ed. La Ley. Buenos Aires, 2010.

MOLINA MORALES, Ranfel. "La Terminación Unilateral del Contrato por Incumplimiento" en Revista de Derecho Privado Externado 17-2009. Universidad Externado de Colombia. Bogotá D.C., 2009.

ORDÓÑEZ ORDÓÑEZ, Andrés. LOS DEBERES RECÍPROCOS DE INFORMACIÓN EN EL CONTRATO DE SEGURO. En Revista Ibero-Latinoamericana de Seguros No. 22. Pontificia Universidad Javeriana. 2005.

OSPINA FERNÁNDEZ, Guillermo. RÉGIMEN GENERAL DE LAS OBLIGACIONES. Ed. Temis. $8^{\text {va }}$ Edición. Bogotá D.C., 1980.

OSSA G. J. Efrén. DERECHO DE SEGUROS. Colombo Editores Ltda. Bogotá D.C., 2007.

RIPPE, Siegbert. LA CONFIGURACIÓN DEL SINIESTRO EN EL SEGURO DE RESPONSABILIDAD CIVIL. En Revista Ibero-Latinoamericana de Seguros. No. 21. 2004.

Superintendencia Financiera de Colombia. Concepto 2007012879-001 del 9 de mayo de 2007. TAMAYO LOMBANA, Alberto. MANUAL DE OBLIGACIONES. Ed. Derecho y ley. Bogotá. 